Key Words:

MCU Saltstone, Hydraulic Conductivity, Moisture Retention

Characteristics

Retention: Permanent

\title{
HYDRAULIC AND PHYSICAL PROPERTIES OF MCU SALTSTONE
}

\author{
Kenneth Dixon \\ Mark Phifer
}

MARCH 2008

Savannah River National Laboratory

Washington Savannah River Company

Savannah River Site

Aiken, SC 29808 


\section{DISCLAIMER}

This report was prepared for the United States Department of Energy under Contract No. DE-AC09-96SR18500 and is an account of work performed under that contract. Neither the United States Department of Energy, nor WSRC, nor any of their employees makes any warranty, expressed or implied, or assumes any legal liability or responsibility for accuracy, completeness, or usefulness, of any information, apparatus, or product or process disclosed herein or represents that its use will not infringe privately owned rights. Reference herein to any specific commercial product, process, or service by trade name, trademark, name, manufacturer or otherwise does not necessarily constitute or imply endorsement, recommendation, or favoring of same by Washington Savannah River Company or by the United States Government or any agency thereof. The views and opinions of the authors expressed herein do not necessarily state or reflect those of the United States Government or any agency thereof.

Printed in the United States of America

Prepared For

U.S. Department of Energy 
Key Words:

MCU Saltstone, Hydraulic Conductivity, Moisture Retention Characteristics

Retention: Permanent

\section{HYDRAULIC AND PHYSICAL PROPERTIES OF MCU SALTSTONE}

MARCH 2008

Savannah River National Laboratory

Washington Savannah River Company

Savannah River Site

Aiken, SC 29808 


\section{TABLE OF CONTENTS}

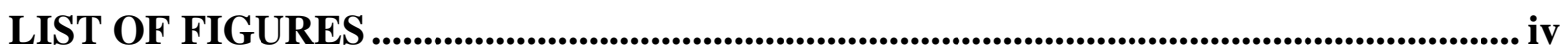

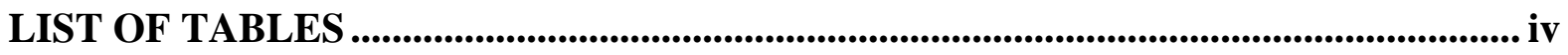

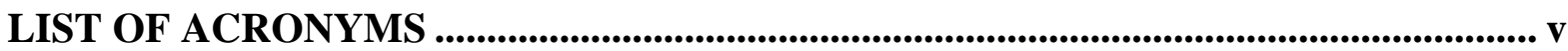

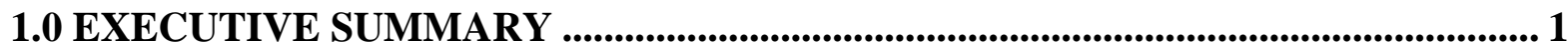

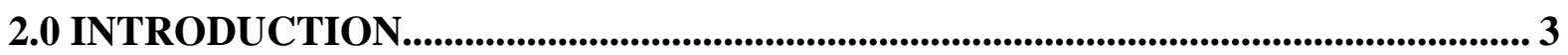

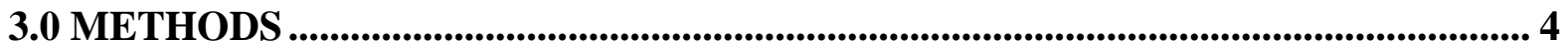

3.1 MCU Saltstone Sample Preparation....................................................................... 4

3.2 Hydraulic and Geotechnical Testing................................................................................ 5

3.2.1 Testing by ASTM Methods..................................................................................... 5

3.2.2 Testing by Steady State Centrifugation-Unsaturated Flow Apparatus .............. 8

3.3 Determination of van Genuchten Transport Parameters.......................................9

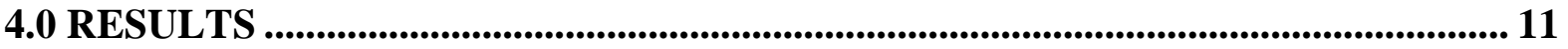

4.1 Hydraulic and Physical Properties of the Saltstone ........................................... 11

4.1.1 Saltstone Hydraulic and Physical Properties as Determined by GTX ............. 11

4.1.2 Saltstone Hydraulic and Physical Properties as Determined by INL .............. 12

4.2 Analysis of Moisture Retention Characteristics ...................................................... 13

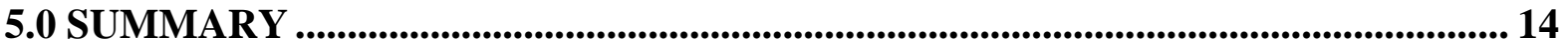

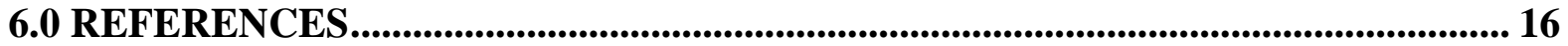

APPENDIX A. Laboratory Notebook Pages from MCU Saltstone Sample Preparation

APPENDIX B. Recipes For Saltstone Pore Fluid and Groundwater Equilibrated With

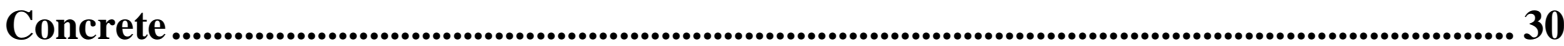

APPENDIX C. INL Report on Testing of MCU Saltstone............................................... 33

APPENDIX D. GTX Data Sheets on MCU Saltstone Testing ..................................... 46

APPENDIX E. Calculations to correct for salt precipitation .......................................... 55 


\section{LIST OF FIGURES}

Figure 1. Combined moisture retention curves for MCU saltstone samples (GTX and INL analyses)

Figure 2. Characteristic curves for MCU saltstone sample SLT003B.................................. 18

Figure 3. Characteristic curves for MCU saltstone sample SLT004B................................... 19

Figure 4. Average characteristic curves for MCU saltstone (SLT003B and SLT004B)....... 19

Figure 5. Characteristic curves for MCU saltstone samples as determined by INL.............. 20

\section{LIST OF TABLES}

Table 1. Saltstone Cementitious Materials ${ }^{1}$.......................................................................... 21

Table 2. Recipe for MCU Simulant used to Prepare MCU Saltstone Samples...................... 21

Table 3. Recipe for Simulated Saltstone Pore Fluid and Simulated Groundwater Equilibrated with Vault Concrete. ..................................................................................................... 21

Table 4. Hydraulic Properties of MCU Saltstone as Measured by GTX (28 day minimum

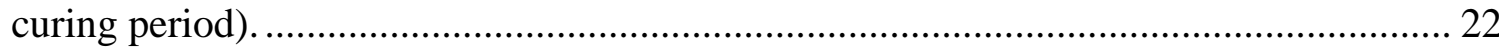

Table 5. Physical Properties of MCU Saltstone as Measured by GTX (28 day minimum

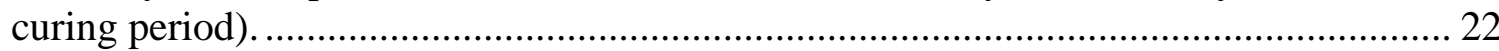

Table 6. Hydraulic Properties of MCU Saltstone as Measured by INL (28 day minimum

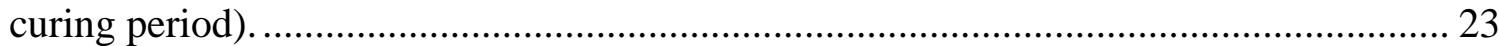

Table 7. Moisture Retention Data for MCU Saltstone (28 day minimum curing period)..... 24

Table 8. Moisture Retention Properties of the MCU Saltstone as measured by INL (28 day minimum curing period). .............................................................................................. 24

Table 9. Van Genuchten Transport Parameters ${ }^{1}$..................................................................... 25

Table 10. Recommended MCU Saltstone Hydraulic Parameter Values Based upon this Study 


\section{LIST OF ACRONYMS}

$\begin{array}{ll}\text { CSSX } & \text { Caustic side solvent extraction } \\ \text { GTX } & \text { Geotesting Express, Inc } \\ \text { INL } & \text { Idaho National Laboratory } \\ \text { MCU } & \text { Modular Caustic Side Solvent Extraction Unit } \\ \text { PA } & \text { Performance Assessment } \\ \text { RETC } & \text { RETention Curve } \\ \text { SDF } & \text { Saltstone Disposal Facility } \\ \text { SRIP } & \text { Site Regulatory Integration and Planning } \\ \text { SRNL } & \text { Savannah River National Laboratory } \\ \text { SRS } & \text { Savannah River Site } \\ \text { SSC-UFA } & \text { Steady State Centrifugation - Unsaturated Flow Apparatus } \\ \text { USDA } & \text { United States Department of Agriculture } \\ \text { USDOE } & \text { United States Department of Energy } \\ \text { w/c } & \text { water to cement ratio } \\ \text { WSRC } & \text { Washington Savannah River Company }\end{array}$




\subsection{EXECUTIVE SUMMARY}

The Saltstone Disposal Facility (SDF), located in the Z-Area of the Savannah River Site (SRS), is used for the disposal of low-level radioactive salt solution. The SDF currently contains two vaults: Vault 1 (6 cells) and Vault 4 (12 cells). Additional disposal cells are currently in the design phase. The individual cells of the saltstone facility are filled with saltstone., Saltstone is produced by mixing the low-level radioactive salt solution, with blast furnace slag, fly ash, and cement or lime to form a dense, micro-porous, monolithic, low-level radioactive waste form. The saltstone is pumped into the disposal cells where it subsequently solidifies. Significant effort has been undertaken to accurately model the movement of water and contaminants through the facility. Key to this effort is an accurate understanding of the hydraulic and physical properties of the solidified saltstone . To date, limited testing has been conducted to characterize the saltstone .

The primary focus of this task was to estimate the hydraulic and physical properties of MCU (Modular Caustic Side Solvent Extraction Unit) saltstone relative to two permeating fluids. These fluids included simulated groundwater equilibrated with vault concrete and simulated saltstone pore fluid. Samples of the MCU saltstone were prepared by the Savannah River National Laboratory (SRNL) and allowed to cure for twenty eight days prior to testing. These samples included two three-inch diameter by six inch long mold samples and three one-inch diameter by twelve inch long mold samples.

The three inch diameter mold samples were submitted to an offsite laboratory for hydraulic and physical property testing. These services were provided by Geotesting Express, Inc. (GTX) per ASTM specifications. Properties measured included saturated hydraulic conductivity, moisture retention characteristics, dry bulk density, and porosity. The hydraulic conductivity of a porous medium is related to the properties of the medium and the permeating fluid (density and viscosity). For this task, measurements of the saturated hydraulic conductivity of saltstone were made using two different fluids: simulated groundwater equilibrated with vault concrete and simulated saltstone pore fluid. The saturated hydraulic conductivity of the saltstone relative to the groundwater equilibrated with vault concrete simulant was estimated by GTX to be $1.5 \times 10^{-8}$ $\mathrm{cm} / \mathrm{sec}$ (Table 4). The saturated hydraulic conductivity of the saltstone relative to the saltstone pore fluid simulant was estimated by GTX to be $5.3 \times 10^{-9} \mathrm{~cm} / \mathrm{sec}$ (Table 4). The dry bulk density of the saltstone was estimated by GTX to range from 0.95 to $1.06 \mathrm{~g} / \mathrm{cm}^{3}$ with an average of $0.99 \mathrm{~g} / \mathrm{cm}^{3}$ (Table 5 and Table 7). The porosity was estimated by GTX to range from 0.578 to 0.613 with an average of 0.596 (Table 5 and Table 7). The saturated hydraulic conductivity and porosity measurements as determined by GTX were comparable to those reported by Harbour et al. (2007) and reflect the high water to cementitious material ratio of the saltstone ( $w / c=0.6)$ and a low degree of reaction. Whereas the saturated hydraulic conductivity and porosity measurements on saltstone samples reported herein and by Harbour et al. (2007) are significantly higher than previous measurements reported by Yu et al. 1993. As outlined by Phifer et al. 2006 the saturated hydraulic conductivity measurements reported by Yu et al. 1993 on saltstone samples may have been artificially low due to use of a brine solution permeant containing nitrate at concentrations greater than saturation values for contact with saltstone. 
In addition, three 1.00-inch diameter by twelve inch long mold samples were submitted to the Idaho National Laboratory (INL) to be tested for saturated hydraulic conductivity, unsaturated hydraulic conductivity, moisture retention characteristics, dry bulk density, and porosity. INL used both a steady state centrifugation-unsaturated flow apparatus (SSC-UFA) and a permeameter to measure the hydraulic properties of the saltstone relative to the two simulants. Both test methods yielded similar results. Hence, the results from the two methods were averaged to provide the best estimate for saturated hydraulic conductivity for each sample. The saturated hydraulic conductivity of the saltstone relative to the groundwater equilibrated with vault concrete simulant ranged from 1.0 to $1.8 \times 10^{-8} \mathrm{~cm} / \mathrm{sec}$ (Table 6). The saturated hydraulic conductivity of the saltstone relative to the saltstone pore fluid simulant ranged from $9.0 \times 10^{-9}$ to $5.3 \times 10^{-8} \mathrm{~cm} / \mathrm{sec}$ (Table 6). The dry bulk density of the saltstone was estimated by INL to range from 0.699 to $0.744 \mathrm{~g} / \mathrm{cm}^{3}$ (Table 8 ). INL did not directly measure the porosity of the saltstone.

The saturated hydraulic conductivity results from both GTX and INL were slightly greater than measurements by Harbour et al. (2007) using a beam bending technique. Harbour et al. (2007) estimated the saturated hydraulic conductivity (relative to water) to be on the order of 1.4 to 3.4 x $10^{-9} \mathrm{~cm} / \mathrm{sec}$. The hydraulic conductivities measured as part of this task and by Harbour et al. (2007) are significantly higher than those previous reported by Yu et al. (1993).

The moisture retention properties of the saltstone were measured by both GTX and INL and are presented in Table 7 and Table 8. The GTX measurements were made using pressure plate apparatus. The INL measurements were made using a variety of methods including hanging column (wet range), pressure plate (mid range), and chilled mirror vapor equilibrium (dry range). These data were then analyzed to determine the van Genuchten transport parameters using the RETC code (USDA, 1998). These parameters may be used to implicitly determine the relationship between unsaturated hydraulic conductivity and moisture content. The results from these analyses are presented in Table 9. 


\subsection{INTRODUCTION}

The Saltstone Disposal Facility (SDF), located in the Z-Area of the Savannah River Site (SRS), is used for the disposal of low-level radioactive salt solution. The SDF currently contains two vaults: Vault 1 and Vault 4. Additional disposal cells are currently in the design phase. Vault 4 is approximately 200 feet wide, 600 feet in length, and 26 feet in height. Vault 4 divided into 12 cells with each cell measuring about 100 feet by 100 feet (Cook et la., 2005). Vault 1 is half the size of Vault 4 measuring approximately 100 feet wide by 600 feet long with 6 cells. The individual cells of the saltstone facility are filled with saltstone. Saltstone is produced by mixing low-level radioactive salt solution, with blast furnace slag, fly ash, and cement or lime to form a is a dense, micro-porous, monolithic, low-level radioactive waste form. The saltstone material contains no coarse aggregate.. The saltstone is pumped into the disposal cells where it subsequently solidifies.

Significant effort has been undertaken to accurately model the movement of water and contaminants through the facility. Key to this effort is an accurate understanding of the hydraulic and physical properties of the saltstone. Limited testing has been conducted to characterize the saltstone. This characterization work indicates that intact saltstone has the following properties: dry bulk density of $1.26 \mathrm{~g} / \mathrm{cm}^{3}$; porosity of $42.3 \%$; saturated intrinsic permeability of $5.3 \times 10^{-9}$ darcies using a brine solution; and saturated hydraulic conductivity relative to water of $5.19 \times 10^{-12} \mathrm{~cm} / \mathrm{s}$ (Yu et al., 1993). It is important to note that the permeability/conductivity values may be biased low due to potential precipitation of the brine solution within the saltstone samples.

Langton (1986) measured the saturated hydraulic conductivity of "Reference Saltstone" samples containing $42.5 \%$ salt solution and $57.5 \%$ (by mass) blended cement. Langton (1986) reported saturated hydraulic conductivity of this material to be $1.1 \times 10^{-8} \mathrm{~cm} / \mathrm{sec}$ for a sample cured for 60 days. Additionally, Langton (1986) reported the results of previous hydraulic testing on saltstone samples (made with varying amounts of salt solution) with results ranging from $3.0 \mathrm{x}$ $10^{-9} \mathrm{~cm} / \mathrm{sec}$ to $<1.0 \times 10^{-11} \mathrm{~cm} / \mathrm{sec}$.

More recently, Harbour et al. (2007) estimated the saturated hydraulic conductivity of a MCU saltstone using a beam bending technique. Harbour et al. (2007) estimated the hydraulic conductivity of the saltstone to range from 1.4 to $3.4 \times 10^{-9} \mathrm{~cm} / \mathrm{sec}$, which is about three orders of magnitude more permeable than reported by Yu et al. (1993). Furthermore, Harbour et al. (2007) reported a porosity of 0.62 which is substantially greater than that reported by Yu et al. (1993).

An upcoming revision to the Z-Area Saltstone Facility Performance Assessment (PA) has provided the motivation to further investigate the hydraulic and physical properties of the saltstone. These properties include saturated hydraulic conductivity, moisture retention characteristics, porosity, and bulk density. The sections that follow discuss the methods used to test samples of the MCU saltstone and the results of the testing. 
WSRC-STI-2007-00649, REVISION 0

\subsection{METHODS}

The objective of this testing was to determine the saturated hydraulic conductivity, moisture retention characteristics, dry bulk density, and porosity of samples of MCU saltstone. Two samples of saltstone were tested to determine the hydraulic and physical properties using standard ASTM methods (or equivalent). The saturated hydraulic conductivity of the saltstone was measured relative to two different permeating fluids.

In addition to the standard testing, samples of the saltstone were tested using steady state centrifugation unsaturated flow apparatus (SSC-UFA) at the Idaho National Laboratory (INL). The goal of this testing was to determine both the saturated and unsaturated hydraulic properties of the saltstone in addition to dry bulk density and porosity.

\subsection{MCU SALTSTONE SAMPLE PREPARATION}

Batches of MCU saltstone were prepared in the laboratory using cementitious materials and a simulated salt solution. A total of three batches were made: 1) TR-229, 2) TR-230, and 3) TR231. Pertinent information from the laboratory notebook on the preparation of the saltstone is contained in Appendix A. The batches were identical in composition except for the amount of caustic side solvent extraction (CSSX) solvent added to each mix. For batches TR-229 and TR230, 100 microliters of CSSX solvent were added to the mix. For batch TR-231, 50 microliters of CSSX solvent were added. The CSSX solvent consists of 0.75 M 1-(2,2,3,3tetrafluoropropoxy)-3-(4-sec-butylphenoxy)-2-propanol (Cs-7SB) and 0.003 M tri-n-octylamine (TOA) in an Isopar ${ }^{\circledR} \mathrm{L}$ diluent.

The premix (cementitious component) used in each batch was comprised of Class $\mathrm{F}$ fly ash (45\%), Grade 100 blast furnace slag (45\%), and Type II Portland cement (10\%) with a water to premix ratio of 0.6 (Table 1). The cementitious materials were mixed with a salt solution representative of the liquid waste to be processed by the saltstone facility (Table 2). This MCU based simulant had a water to simulant ratio of 0.68 (on a mass basis) and a density of 1.261 $\mathrm{g} / \mathrm{cm}^{3}$.

Using a standard 3 inch diameter ASTM mold, one test cylinder was made from batch TR-229 and one test cylinder was made from batch TR-230. The mold samples were capped, sealed, and allowed to cure in the laboratory at ambient temperature for a minimum of 28 days. One inch diameter cylinders were also prepared using polybutyrate liners 12 inches in length. A one inch diameter cylinder was made from batch TR-229 and TR-230 and two one-inch diameter cylinders were made from batch TR-231. The cylinders were capped, sealed, and allowed to cure in the laboratory at ambient temperature for a minimum of 28 days. The twenty eight day cure date for all the test cylinders was 4/25/2006. 
WSRC-STI-2007-00649, REVISION 0

\subsection{HYDRAULIC AND GEOTECHNICAL TESTING}

\subsubsection{Testing by ASTM Methods}

The MCU saltstone samples were submitted for testing per standard ASTM methods (or equivalent) to Geotesting Express, Inc. (GTX). A total of two 3-inch diameter samples were shipped to the lab including one from batch TR-229 (SLT003) and one from batch TR-230 (SLT004). These samples were cured for a minimum of 28 days.

Two simulants were used to permeate the samples: simulated groundwater equilibrated with vault concrete and simulated saltstone pore fluid. Sample SLT003 was tested for saturated hydraulic conductivity with the equilibrated groundwater simulant. The equilibrated groundwater simulant was based upon groundwater analysis from well P16-B equilibrated with the vault cement composition as described by Denham (2006). Sample SLT004 was tested for saturated hydraulic conductivity with the simulated saltstone pore fluid. The simulated saltstone pore fluid was developed by SRNL based on estimated saltstone pore fluid characteristics and is similar to the MCU simulant used to batch the saltstone samples. Appendix B gives the details of how both simulants were developed. The recipes for the simulants are provided in Table 3. The saturated hydraulic conductivity of the saltstone was estimated relative to each simulant following ASTM D 5084 Method E - flexible wall permeameter (Constant Volume).

GTX also measured the specific gravity (ASTM D 854), dry bulk density (ASTM C 642 equivalent), porosity (ASTM C 642 equivalent), and moisture retention properties of the saltstone samples (ASTM D 2325). The saltstone samples were assumed to be saturated when received by the laboratory (with excess MCU simulant from hydration). This is a valid assumption due to the high water to cement ratio of the saltstone (0.6) and the low degree of hydration of MCU saltstone (Harbour et al., 2007). This was confirmed by successive weight measurements made on samples under vacuum saturation. The samples showed no significant weight gain during saturation with either the saltstone pore fluid simulant or the groundwater equilibrated with vault concrete simulant. Therefore, it is assumed that the dry bulk density, porosity, and moisture retention measurements were made with the MCU simulant as the interstitial liquid rather than the saltstone pore fluid simulant or the equilibrated groundwater simulant.

The dry bulk density, porosity, and moisture retention measurements made by GTX were adjusted based on the properties of the MCU simulant used to batch the saltstone samples. The adjustment was necessary because the MCU simulant (which is the interstitial liquid) contained salts that were precipitated during the oven drying process associated with each of these tests. The raw laboratory results from these tests are presented in Appendices $C$ and $D$. Calculations which illustrate the adjustments made to the laboratory data are presented in Appendix E. The results presented in the body of this report have been adjusted for salt precipitation and therefore differ from the raw laboratory measurements presented in Appendices C and D. 
GTX determined dry bulk density dividing the oven dried weight of the sample by the measured volume (modified ASTM C 642). The resulting values were then corrected for each sample as illustrated in Appendix E using the following equations.

$$
\begin{aligned}
& \psi_{\text {liquid }}=\frac{\rho_{\text {sat }}-\rho_{\text {oven }}}{\chi_{\text {wil }}} \\
& \rho_{\text {dry }}=\rho_{\text {sat }}-\psi_{\text {liquid }}
\end{aligned}
$$

$\psi_{\text {liquid }}=$ unit mass of interstitial liquid in sample at saturation, $\mathrm{g} / \mathrm{cm}^{3}$

$\rho_{\text {sat }}=$ wet density of saturated sample, $\mathrm{g} / \mathrm{cm}^{3}$

$\rho_{\text {oven }}=$ oven dried density of sample, $\mathrm{g} / \mathrm{cm}^{3}$

$\chi_{\text {wil }}=$ mass fraction of water in interstitial liquid (0.68), fraction

$\rho_{\text {dry }}=$ dry bulk density, $\mathrm{g} / \mathrm{cm}^{3}$

Porosity $(\phi)$ was calculated using the following equations. Example calculations are presented in Appendix E.

$$
\begin{aligned}
& M_{\text {liquid }}=\frac{M_{\text {sat }}-M_{\text {dry }}}{\chi_{\text {wil }}} \\
& V_{\text {liquid }}=\frac{M_{\text {liquid }}}{\rho_{\text {liquid }}} \\
& \phi=\frac{V_{\text {voids }}}{V_{\text {total }}}=\frac{V_{\text {liquid }}}{V_{\text {total }}}
\end{aligned}
$$

$\mathrm{M}_{\text {liquid }}=$ mass of interstitial liquid in sample at saturation, $\mathrm{g}$

$\mathrm{M}_{\text {sat }}=$ mass of saturated sample, $\mathrm{g}$

$\mathrm{M}_{\text {dry }}=$ mass of oven dried sample, $\mathrm{g}$

$\chi_{\text {wil }}=$ mass fraction of water in interstitial liquid (0.68), fraction

$\mathrm{V}_{\text {voids }}=$ total volume of voids, $\mathrm{cm}^{3}$

$\mathrm{V}_{\text {liquid }}=$ volume of interstitial liquid in sample, $\mathrm{cm}^{3}$

$\mathrm{V}_{\text {total }}=$ total volume of sample, $\mathrm{cm}^{3}$

$\rho_{\text {liquid }}=$ density of interstitial liquid $\left(1.261 \mathrm{~g} / \mathrm{cm}^{3}\right), \mathrm{g} / \mathrm{cm}^{3}$

$\phi=$ porosity, fraction 
Moisture retention characteristics were determined using method ASTM D 2325 by pressure plate apparatus. For moisture retention analysis, the saturated samples were weighed to determine an initial weight. These samples were then subjected to increasing pressures in a pressure plate apparatus. Between each increase in pressure, the samples were weighed. Following the final pressure increase, the samples were weighed and then oven dried. The following equations were then used to determine the initial moisture content (i.e. porosity) of the samples. Example calculations are presented in Appendix E.

$$
\begin{aligned}
& M_{\text {liquid-pressure }}=M_{\text {sat }}-M_{\text {pressure-final }} \\
& M_{\text {liquid-oven }}=\frac{M_{\text {pressure-final }}-M_{\text {dry }}}{\chi_{\text {wil }}} \\
& M_{\text {liquid }}=M_{\text {liquid-pressure }}+M_{\text {liquid-oven }} \\
& V_{\text {liquid }}=\frac{M_{\text {liquid }}}{\rho_{\text {liquid }}} \\
& \phi=\frac{V_{\text {voids }}}{V_{\text {total }}}=\frac{V_{\text {liquid }}}{V_{\text {total }}}
\end{aligned}
$$

$\mathrm{M}_{\text {liquid-pressure }}=$ mass of interstitial liquid removed by pressure extraction, $\mathrm{g}$ $\mathrm{M}_{\text {liquid-oven }}=$ mass of interstitial liquid removed by oven drying, $\mathrm{g}$

$\mathrm{M}_{\text {pressure-final }}=$ final mass of sample following pressure extraction, $\mathrm{g}$

$\mathrm{M}_{\mathrm{sat}}=$ total mass of saturated sample, $\mathrm{g}$

$\mathrm{M}_{\text {liquid }}=$ mass of interstitial liquid in sample at saturation, $\mathrm{g}$

$\mathrm{M}_{\mathrm{dry}}=$ mass of oven dried sample, $\mathrm{g}$

$\chi_{\text {wil }}=$ mass fraction of water in interstitial liquid (0.68), fraction

$\mathrm{V}_{\text {liquid }}=$ volume of interstitial liquid in sample, $\mathrm{cm}^{3}$

$\mathrm{V}_{\text {voids }}=$ total volume of voids, $\mathrm{cm}^{3}$

$\mathrm{V}_{\text {total }}=$ total volume of sample, $\mathrm{cm}^{3}$

$\phi=$ porosity, fraction

$\rho_{\text {liquid }}=$ density of interstitial liquid $\left(1.261 \mathrm{~g} / \mathrm{cm}^{3}\right), \mathrm{g} / \mathrm{cm}^{3}$ 
The following equations were used to determine the volumetric moisture content of the samples at each pressure increment. Example calculations are presented in Appendix E.

$$
\begin{aligned}
& M_{\text {solid }}=M_{\text {sat }}-M_{\text {liquid }} \\
& V_{\text {liquid }}=\frac{M_{\text {sample }}-M_{\text {solid }}}{\rho_{\text {liquid }}} \\
& \theta_{\text {liquid }}=\frac{V_{\text {liquid }}}{V_{\text {total }}} \\
& \mathrm{M}_{\mathrm{sat}}=\text { total mass of saturated sample, } \mathrm{g} \\
& \mathbf{M}_{\text {sample }}=\text { mass of sample at each pressure increment, } \mathrm{g} \\
& \mathrm{M}_{\text {liquid }}=\text { mass of interstitial liquid in sample at saturation, } \mathrm{g} \\
& \mathrm{M}_{\text {solid }}=\text { corrected final dry weight of sample, } \mathrm{g} \\
& \rho_{\text {liquid }}=\text { density of interstitial liquid }\left(1.261 \mathrm{~g} / \mathrm{cm}^{3}\right), \mathrm{g} / \mathrm{cm}^{3} \\
& \mathrm{~V}_{\text {liquid }}=\text { volume of liquid in sample at each pressure increment, } \mathrm{cm}^{3} \\
& \mathrm{~V}_{\text {total }}=\text { total volume of sample, } \mathrm{cm}^{3} \\
& \theta_{\text {liquid }}=\text { volumetric moisture content of sample at each pressure increment, } \\
& \text { fraction }
\end{aligned}
$$

\subsubsection{Testing by Steady State Centrifugation-Unsaturated Flow Apparatus}

A one inch diameter by twelve inch long mold sample from each of the three MCU saltstone batches was submitted to INL for testing using a steady state centrifugation unsaturated flow apparatus (SSC-UFA) following method ASTM D 6527 and procedures given in Methods of Soil Analysis (Dane and Topp, 2002). INL encountered problems potting the saltstone samples in the epoxy casts for testing in the centrifuge. Samples from batches TR229 and TR230 were consumed in the process of developing a method to successfully cast the saltstone samples into epoxy. After selection of a compatible ceramic epoxy, four sub-cores from batch TR231 were successfully cast for testing in the centrifuge. A complete discussion of the methods used is given in the project report in Appendix C (Mattson, 2006).

The SSC-UFA was used to estimate the saturated and unsaturated hydraulic conductivity of the saltstone samples. INL also measured the moisture retention characteristics of the saltstone samples by testing sub-cores of the samples over a range of pressures from $102 \mathrm{~cm} \mathrm{H}_{2} \mathrm{O}(0.1 \mathrm{bar})$ to approximately 57,106 cm of $\mathrm{H}_{2} \mathrm{O}$ ( $\sim 56$ bars). A combination of methods was used to establish the moisture retention curve including hanging column analysis (for the wet end of the curve), pressure plate apparatus (for the middle portion of the curve), and chilled mirror analysis (for the dry end of the curve). See Appendix $\mathrm{C}$ for a complete discussion of the methods. The moisture retention measurements were adjusted to account for salt precipitation during drying in a manner similar to that described in Section 3.2.1. However, the sample mass at each pressure increment 
was unknown for the moisture retention data. Therefore, an adjustment was made with the assumption that the bulk of water loss was from drying (not from extraction). The small error associated with this assumption is acceptable since very little drainage occurred during the moisture retention tests.

$$
\theta_{\text {liquid }}=\frac{\theta_{\text {water }}}{\rho_{\text {liquid }} \chi_{\text {wil }}}
$$

$\theta_{\text {liquid }}=$ volumetric liquid content of sample at each pressure increment

$\theta_{\text {water }}=$ volumetric water content of sample at each pressure increment

$\rho_{\text {liquid }}=$ density of interstitial liquid $\left(1.261 \mathrm{~g} / \mathrm{cm}^{3}\right), \mathrm{g} / \mathrm{cm}^{3}$

$\chi_{\text {wil }}=$ mass fraction of water in interstitial liquid (0.68), fraction

The dry bulk density of the saltstone was determined following the method of Dane and Topp (2002) where the dry weight of the sample is divided by the measured volume (equivalent to ASTM C 642). The dry bulk density measurements were adjusted to account for salt precipitation during drying as described in Section 3.2.1. Porosity was estimated based on the moisture retention data using the RETC code (USDA, 1998).

\subsection{DETERMINATION OF VAN GENUCHTEN TRANSPORT PARAMETERS}

Direct measurement of the unsaturated hydraulic conductivity of large numbers of samples of cementitious materials is time consuming and cost prohibitive. An alternative to direct measurement is the use of theoretical methods to predict the unsaturated hydraulic conductivity based upon measured moisture retention data. These methods are generally based on pore-size distribution models, and have been shown to perform reasonably well for coarse textured soils and other porous media having relatively narrow pore-size distributions (USDA, 1998). The applicability of these models to cementitious materials has not been fully assessed; nevertheless, predictive models based on moisture retention data provide the most viable means of characterizing the hydraulic properties of large numbers of samples of cementitious materials. Therefore, this method was chosen to predict the unsaturated hydraulic conductivity of the MCU saltstone samples based upon the measured moisture retention properties.

RETC (RETention Curve) (USDA, 1998), a U.S. Salinity Laboratory computer program designed for analyzing the hydraulic properties of unsaturated soils, was used to fit the measured moisture retention data for the saltstone samples. The program's curve fitting is based on van Genuchten's equation for soil moisture content as a function of pressure

$$
\begin{array}{rr}
\theta(h)=\theta_{r}+\frac{\theta_{s}-\theta_{r}}{\left[1+(\alpha h)^{n}\right]^{m}} & h \leq 0 \\
\theta(h)=\theta_{s} & h>0
\end{array}
$$


where $\theta(h)$ is moisture content at the pressure head $h, \theta_{r}$ is residual moisture content, $\theta_{s}$ is the saturated moisture content, $h$ is pressure head, $\alpha$ is a constant related to the inverse of the airentry pressure, and $n$ is a measure of the pore-size distribution. The constraint $m=1-1 / n$ was used as suggested by van Genuchten (van Genuchten, 1980; van Genuchten et al, 1991).

The generated moisture retention curves were based on moisture retention data only; no unsaturated hydraulic conductivity data were available for the samples. RETC's (USDA, 1998) van Genuchten $m=1-1 / n$ retention curve model was used to estimate curve fitting parameters $\left(\theta_{r}, \theta_{s}, \alpha, n\right)$ for each sample.

The curve fitting parameters $\left(\theta_{r}, \theta_{s}, \alpha, n\right)$ from RETC (USDA, 1998) were used to calculate the effective saturation (or reduced water content), $S_{e}$, at incremental pressure heads according to

$$
S_{e}=\frac{S-S_{r}}{1-S_{r}}=\frac{1}{\left[1+(\alpha h)^{n}\right]^{m}}
$$

where $S_{r}$ denotes residual saturation. Using $S_{e}$, the relative hydraulic conductivity was calculated at incremental pressure heads using the Mualem-van Genuchten type function

$$
K=S_{e}^{L}\left[1-\left(1-S_{e}^{1 / m}\right)^{m}\right]^{2}, \begin{aligned}
& \text { where } L \text { is an empirical pore-connectivity parameter and assumed } \\
& \text { to be } 0.5 .
\end{aligned}
$$

Saturation ( $S$ ) was calculated at various pressure heads according to

$$
S=S_{r}+\left(\frac{1-S_{r}}{\left[1+(\alpha h)^{n}\right]^{m}}\right)
$$

where residual saturation, $S_{r}$, is equal to $\theta_{r} / \theta_{s}$ (the residual moisture content divided by the saturated moisture content). 


\subsection{RESULTS}

Two three-inch diameter samples of MCU saltstone were tested to estimate hydraulic conductivity, moisture retention characteristics, porosity, and bulk density using standard ASTM methods (or equivalent). For saturated hydraulic conductivity, each sample was tested with a different permeating fluid. The simulants used to permeate the samples included simulated groundwater equilibrated with vault concrete and simulated saltstone pore fluid. Additionally, one one-inch diameter sample of the MCU saltstone was tested using steady state centrifugation to estimate the hydraulic properties of the material relative to the two simulants.

\subsection{HYDRAULIC AND PHYSICAL PROPERTIES OF THE SALTSTONE}

GTX estimated the hydraulic and physical properties of the MCU saltstone samples using ASTM methods (or equivalent), while INL used the SSC-UFA and standard soil science methods (Methods of Soil Analysis; Dane and Topp, 2002). The supporting detailed test reports produced by GTX are provided in Appendix D, and the report detailing the INL results is included in Appendix C.

\subsubsection{Saltstone Hydraulic and Physical Properties as Determined by GTX}

Two samples were tested by GTX to estimate the hydraulic and physical properties of the MCU saltstone. For hydraulic conductivity, each sample was tested with a different simulant. Sample SLT003 was tested with a simulant intended to be representative of groundwater equilibrated with vault concrete (Table 3). Sample SLT004 was tested with a simulant intended to be representative of saltstone pore fluid (Table 3). The results of the testing are presented in Table 4. The saturated hydraulic conductivity of sample SLT003, which was permeated with the groundwater simulant equilibrated with vault concrete, was estimated to be $1.5 \times 10^{-8} \mathrm{~cm} / \mathrm{sec}$. The saturated hydraulic conductivity of sample SLT004, which was permeated with the saltstone pore fluid simulant, was estimated to be $5.3 \times 10^{-9} \mathrm{~cm} / \mathrm{sec}$.

The dry bulk density of sample SLT003 was estimated to be $0.95 \mathrm{~g} / \mathrm{cm}^{3}$ and the porosity was estimated to be 0.613 (adjusted for salt precipitation). The particle density of sample SLT003 was estimated to be $2.45 \mathrm{~g} / \mathrm{cm}^{3}$. The dry bulk density of sample SLT004 was estimated to be $0.98 \mathrm{~g} / \mathrm{cm}^{3}$ and the porosity was estimated to be 0.600 (adjusted for salt precipitation). The particle density of sample SLT004 was estimated to be $2.48 \mathrm{~g} / \mathrm{cm}^{3}$. The high total porosity and low bulk density observed for the saltstone samples may be attributed to the high water to cementitious material ratio $(\mathrm{w} / \mathrm{c}=0.6)$ and low degree of cementitious material reaction.

The moisture retention properties of the saltstone were determined following method ASTM D 2325. The results are presented in Table 7 and are adjusted for salt precipitation as described in Section 3.2.1. As stated earlier, the samples were considered to be saturated with the MCU simulant used to batch the saltstone samples. GTX tested two samples, SLT003 and SLT004, at pressures ranging from $102 \mathrm{~cm} \mathrm{H}_{2} \mathrm{O}$ (0.1 bars) to 15,296 cm $\mathrm{H}_{2} \mathrm{O}$ (15 bars), Table 7. GTX tested wafers approximately 3 inches in diameter and $1 / 2$ inch thick from the top and bottom of each sample using a pressure plate apparatus. The wafers taken from the top of both samples 
(SLT003 and SLT004) cracked during the moisture retention testing and these results were discarded. Cracking of the top portion of the samples may be indicative of saltstone component segregation due to settling prior to sample gelling. Moisture retention curves were prepared for the wafers taken from the bottom of each sample, Figure 1.

\subsubsection{Saltstone Hydraulic and Physical Properties as Determined by INL}

Sub-samples from a one inch diameter MCU saltstone sample were tested by INL for saturated hydraulic conductivity relative to the two simulants: the groundwater equilibrated with vault concrete simulant and the saltstone pore fluid simulant. The results of this testing are presented in Table 6. INL estimated the saturated hydraulic conductivity of the saltstone material using two methods, falling head permeameter and SSC-UFA. As shown in Table 6, results from both methods were comparable. Thus, the results from the two methods were arithmetically averaged for each sample. INL tested two samples with the vault concrete equilibrated groundwater simulant. The saturated hydraulic conductivity of these two samples relative to the simulant was estimated to be $9.0 \times 10^{-9} \mathrm{~cm} / \mathrm{sec}$ and $1.9 \times 10^{-8} \mathrm{~cm} / \mathrm{sec}$. INL tested two samples with the saltstone pore fluid simulant. The saturated hydraulic conductivity of these two samples relative to the simulant was estimated to be $1.0 \times 10^{-8} \mathrm{~cm} / \mathrm{sec}$ and $1.8 \times 10^{-8} \mathrm{~cm} / \mathrm{sec}$. The dry bulk density of the saltstone samples tested by INL was estimated to range from 0.699 and $0.744 \mathrm{~g} / \mathrm{cm}^{3}$, with an arithmetic average of $0.725 \mathrm{~g} / \mathrm{cm}^{3}$ (adjusted for salt precipitation).

Several samples were analyzed using SCC-UFA to determine the unsaturated properties of the saltstone. However, INL was unable to directly measure the unsaturated hydraulic conductivity using the UFA due to the fine texture of the saltstone. This is discussed in detail in the INL report contained in Attachment C.

INL measured the moisture retention characteristics of the saltstone samples by testing sub-cores of the saltstone over a range of pressures from 0 to approximately 56,086 cm of $\mathrm{H}_{2} \mathrm{O}$ ( $\sim 55$ bars). A combination of methods was used to establish the moisture retention curve including hanging column analysis (for the wet end of the curve), pressure plate apparatus (for the middle portion of the curve), and chilled mirror analysis (for the dry end of the curve). The results from the moisture retention testing are given in Table 8 (adjusted for salt precipitation). Moisture retention curves were prepared for each sample and are shown in Figure 1 in combination with the moisture retention curves as measured by GTX.

In general, the saturated hydraulic conductivity values reported by both INL and GTX were comparable for the two test fluids. However, the dry bulk density measurements reported by INL were substantially lower than those reported by GTX. Additionally, the volumetric liquid content values for the INL samples were substantially greater than those reported by GTX, which is consistent with the lower dry bulk density values. These results may be an artifact of the smaller diameter sample size used for the INL testing. This combined with the previously reported cracking of the top portion of the GTX samples used for moisture retention testing, indicates that the geometry of the sample molds may influence both the formation of bleed water and saltstone component segregation prior to gelling of the sample. The formation of bleed water and component segregation may be inhibited in samples prepared in long, small diameter molds. This in turn could impact the measured bulk density. 


\subsection{ANALYSIS OF MOISTURE RETENTION CHARACTERISTICS}

The measured moisture retention data for the MCU saltstone mix as determined by GTX (following a 28 day curing period) were analyzed using the RETC code (USDA, 1998) to determine the van Genuchten transport parameters and the relative hydraulic conductivity function. The standard Mualem relationship between $n$ and $m$ (i.e., $m=1-1 / n$ ) was used. A separate RETC analysis was performed on each data set. All moisture retention values were given a weight of 1 . The characteristic curves are presented in Figure 2 and Figure 3. The transport parameters are given in Table 9. A reasonable fit of the data for SLT003B was obtained by fixing the residual moisture content to a value of 0.55 while allowing RETC to fit all other parameters (except m). For sample SLT004B, all parameters were fitted (except m). Additionally, the moisture retention data for SLT003B and SLT004B were averaged to produce an average characteristic curve. For this analysis, the residual moisture content was set to a value of 0.55 while allowing RETC to fit all other parameters (except m). A good fit of the data was obtained as shown in Figure 4.

RETC was also used to analyze the moisture retention data measured by INL. The data from both INL samples were combined for the RETC analysis. A poor fit of the data was obtained from RETC $\left(r^{2}=0.57\right)$. The fit produced by RETC was used as a starting point in a visual curve matching procedure where the curve fitting parameters $\alpha$ and $\mathrm{n}$ were adjusted while fixing $\theta_{\mathrm{s}}$ $(0.70)$ and $\theta_{\mathrm{r}}(0.55)$. The results of the visual curve match to the INL data are presented Figure 5 and Table 9. The INL samples had a higher saturated moisture content (0.7) and a higher residual moisture content (0.55) than was determined with the GTX data. Also, more drainage was observed for the same applied pressure for the INL samples compared to the samples tested by GTX. This is expressed in a larger value for the curve fitting parameter $\alpha$, which is the inverse of the air entry pressure (compared to the average case for the GTX data). As expected, the curve fitting parameter $\mathrm{n}$ was similar for the INL analysis and the analysis of the average GTX data indicating similar pore size distributions for the tested samples. 
WSRC-STI-2007-00649, REVISION 0

\subsection{SUMMARY}

The primary focus of this task was to determine the hydraulic and physical properties of MCU saltstone. Saturated hydraulic conductivity was determined relative to two permeating fluids. These fluids included simulated groundwater equilibrated with vault concrete and simulated saltstone pore fluid. Samples of the saltstone were prepared by SRNL and allowed to cure for twenty eight days prior to testing. These samples included two, three inch diameter mold samples and three, one inch diameter mold samples.

The three inch diameter mold samples were submitted to an offsite laboratory for hydraulic and physical property testing following a minimum 28 day curing period. These services were provided by Geotesting Express, Inc. (GTX) per ASTM specifications (or equivalent). Properties measured included saturated hydraulic conductivity, moisture retention characteristics, dry bulk density, and porosity. Saturated hydraulic conductivity was measured relative to the two aforementioned simulants. The saturated hydraulic conductivity of the saltstone relative to the groundwater equilibrated with vault concrete simulant was estimated by GTX to be $1.5 \times 10^{-8}$ $\mathrm{cm} / \mathrm{sec}$ (Table 4). The saturated hydraulic conductivity of the saltstone relative to the saltstone pore fluid simulant was estimated by GTX to be $5.3 \times 10^{-9} \mathrm{~cm} / \mathrm{sec}$ (Table 4). The dry bulk density of the saltstone was estimated to range from 0.95 to $1.06 \mathrm{~g} / \mathrm{cm}^{3}$ with an average of 0.99 $\mathrm{g} / \mathrm{cm}^{3}$ (Table 5 and Table 7). The porosity was estimated to range from 0.578 to 0.613 with an average of 0.596 (Table 5 and Table 7). The moisture retention data as measured by GTX are presented in Table 7.

Three, 1.0 inch diameter by 12 inch long cylindrical samples were submitted to the Idaho National Laboratory (INL) to be tested for hydraulic conductivity, moisture retention characteristics, dry bulk density, and porosity. INL used SSC-UFA and a falling head permeameter to measure the hydraulic properties of the saltstone relative to the two simulants. The saturated hydraulic conductivity of the saltstone relative to the groundwater equilibrated with vault concrete simulant ranged from 1.0 to $1.8 \times 10^{-8} \mathrm{~cm} / \mathrm{sec}$ (Table 6). The saturated hydraulic conductivity of the saltstone relative to the saltstone pore fluid simulant ranged from $9.0 \times 10^{-9}$ to $1.9 \times 10^{-8} \mathrm{~cm} / \mathrm{sec}$ (Table 6). The dry bulk density of the saltstone was estimated to range from 0.699 to $0.744 \mathrm{~g} / \mathrm{cm}^{3}$ (Table 8) with an average of $0.725 \mathrm{~g} / \mathrm{cm}^{3}$. The moisture retention data as measured by INL are presented in Table 8. Based on the RETC analysis of the moisture retention data, the porosity of the samples tested by INL was about 0.70 .

INL attempted to determine the unsaturated properties of the saltstone using SSC-UFA. However, they were unable to directly measure the unsaturated hydraulic conductivity of the saltstone samples using the UFA due to the fine texture of the saltstone.

Harbour et al. 2007 reported an MCU saltstone dry bulk density and porosity of $0.99 \mathrm{~g} / \mathrm{cm}^{3}$ and 0.62, respectively. The MCU saltstone average dry bulk density and average porosity of 0.99 $\mathrm{g} / \mathrm{cm}^{3}$ and 0.596, respectively, reported herein for the 3-inch diameter samples tested by GTX compare very well with the results from Harbour et al. 2007. However the average dry bulk density and porosity of $0.725 \mathrm{~g} / \mathrm{cm}^{3}$ and 0.70 , respectively, reported herein for the 1-inch diameter samples tested by INL do not compare well with the Harbour et al. 2007 and GTX data 
reported herein. Due to the good agreement between the Harbour et al. 2007 and GTX data reported herein and the lack of agreement with the INL data reported herein and the previously stated concerns associated with MCU saltstone sample preparation within the 1.0 inch diameter by 12 inch long polybutyrate liners, it is recommended that only the GTX produced average MCU saltstone data reported herein be utilized (Table 10). Additionally it is recommended that consideration be given to the impact of sample mold geometry on the formation of bleed water and component segregation prior to gelling of the sample. Laboratory samples should be prepared in a way that is as representative of field pour conditions as possible. 
WSRC-STI-2007-00649, REVISION 0

\subsection{REFERENCES}

ASTM C 642. Standard Test Method for Density, Absorption, and Voids in Hardened Concrete. ASTM International, West Conshohocken, PA.

ASTM D 854. Standard Test Methods for Specific Gravity of Soil Solids by Water Pycnometer. ASTM International, West Conshohocken, PA.

ASTM D 2325. Standard Test Method for Capillary-Moisture Relationships for Coarse- and Medium-Textured Soils by Porous-Plate Apparatus. ASTM International, West Conshohocken, PA.

ASTM D 5084. Standard Test Methods for Measurement of Hydraulic Conductivity of Saturated Porous Materials Using a Flexible Wall Permeameter. ASTM International, West Conshohocken, PA.

ASTM D 6527. Standard Test Method for Determination of Unsaturated and Saturated Hydraulic Conductivity of Porous Media by Steady-State Centrifugation. ASTM International, West Conshohocken, PA.

Dane, J. H. and G. C. Topp. Methods of Soil Analysis, Part 4 - Physical Methods. Soil Science Society of America, Madison, WI.

Denham, M. E. 2006. Thermodynamic and Mass Balance of Expansive Phase Precipitation in Saltstone - DRAFT. WSRC-TR-2006-00035. Westinghouse Savannah River Company, Savannah River Site, Aiken SC.

Harbour, J. R., T. B. Edwards, V. J. Williams, G. W. Scherer, and D. M. Feliciano. 2007. Permeability of Saltstone - Measurement by Beam Bending. WSRC-TR-2007-00437. Washington Savannah River Company, Savannah River Site, Aiken SC.

Langton, C. A. 1986. Saltstone Permeability (Hydraulic Conductivity). Report No. DPST-85982, October 1986.

Mattson, E. D. 2006. Data Report for Savannah River Site - Saltstone Cores (INL/MIS-0611865). CCN 207262. Idaho National Laboratory, Idaho Falls, ID.

Phifer, M. A., M. R. Millings, and G. P. Flach. 2006. Hydraulic Property Data Package for the EArea and Z-Area Soils, Cementitious Materials, and Waste Zones. WSRC-STI-200600198, revision 0. Washington Savannah River Company, Savannah River Site, Aiken SC.

USDA, 1998. RETC for Windows, 1998, Version 1.0.0.1, U.S. Salinity Laboratory, U.S. Department of Agriculture (USDA), www.ars.usda.gov/Services/docs.htm?docid=8952. 
Van Genuchten, M. Th., 1980, A Closed-form Equation for Predicting the Hydraulic Conductivity of Unsaturated Soils, Soil Science Society of America Journal, v44, 892898.

Van Genuchten, M. Th., F. J. Leij, and S. R. Yates, 1991, The RETC Code for Qualifying the Hydraulic Functions of Unsaturated Soils, Version 1.0, EPA Report 600/2-91/065, U.S. Salinity Laboratory, USDA, ARS, Riverside, California.

Yu, A. D., C. A. Langton, and M. G. Serrato. 1993. Physical Properties Measurement Program (U). WSRC-RP-93-894. Westinghouse Savannah River Company, Aiken, South Carolina. 


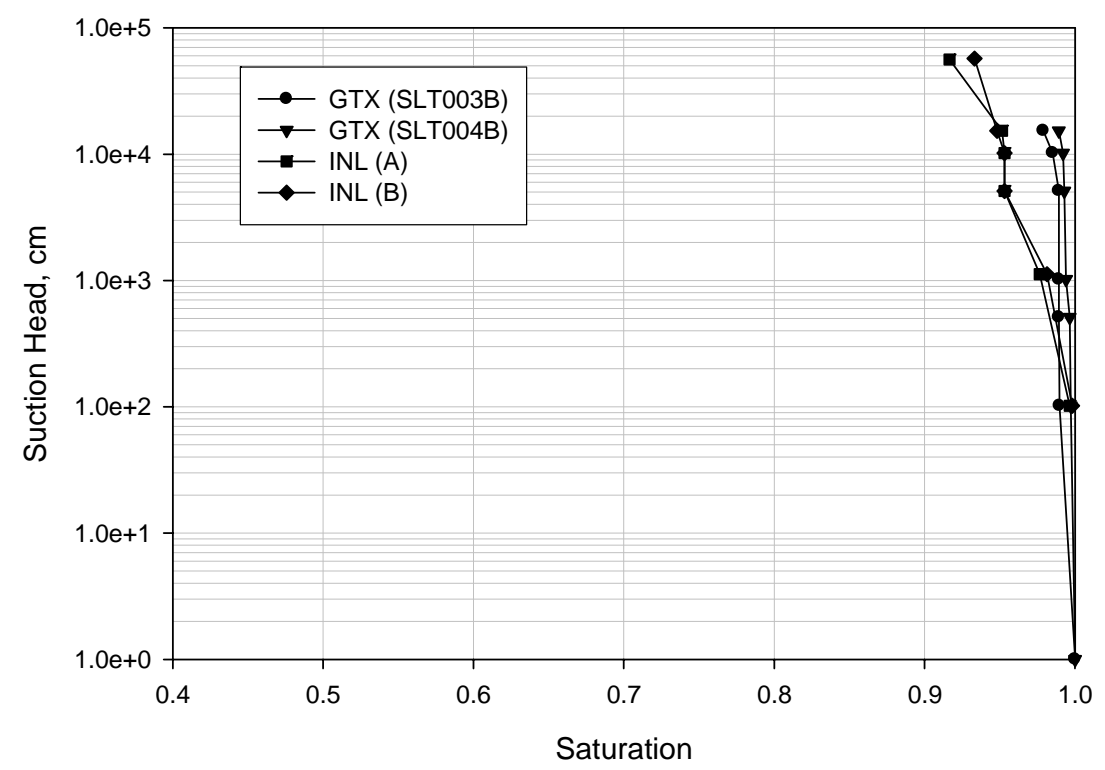

Figure 1. Combined moisture retention curves for MCU saltstone samples (GTX and INL analyses).

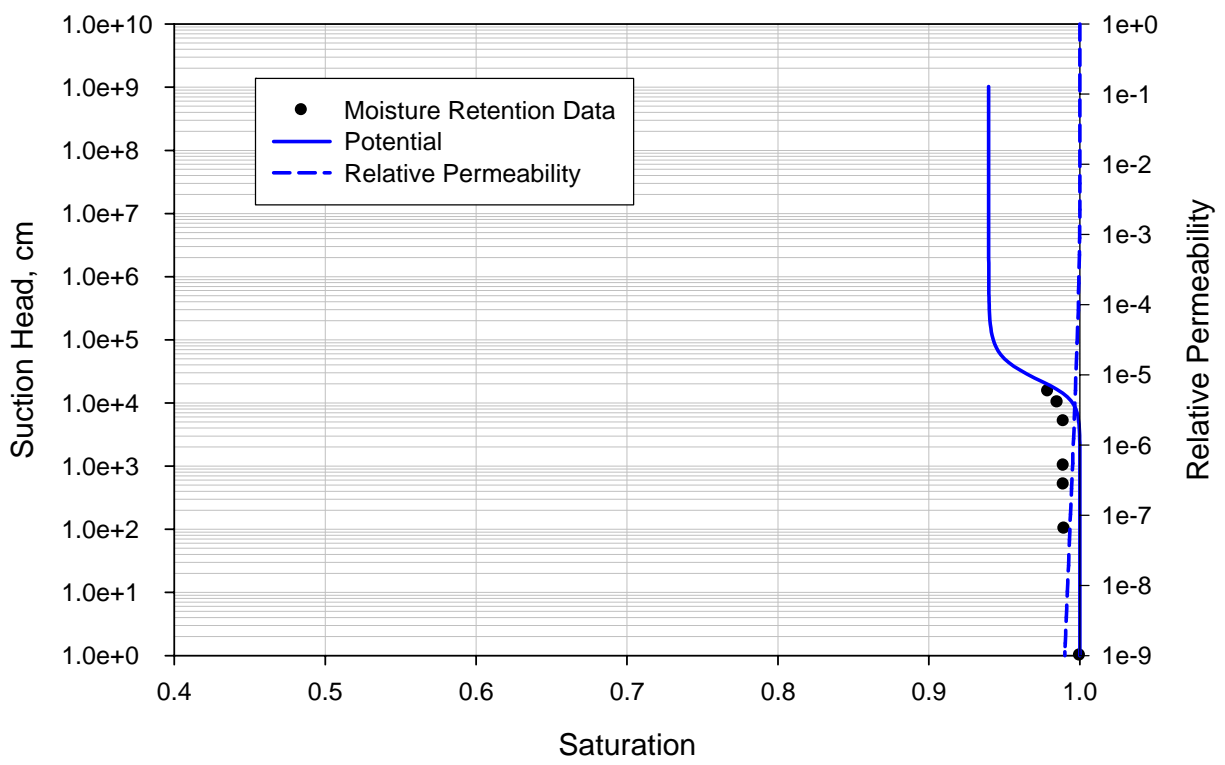

Figure 2. Characteristic curves for MCU saltstone sample SLT003B. 


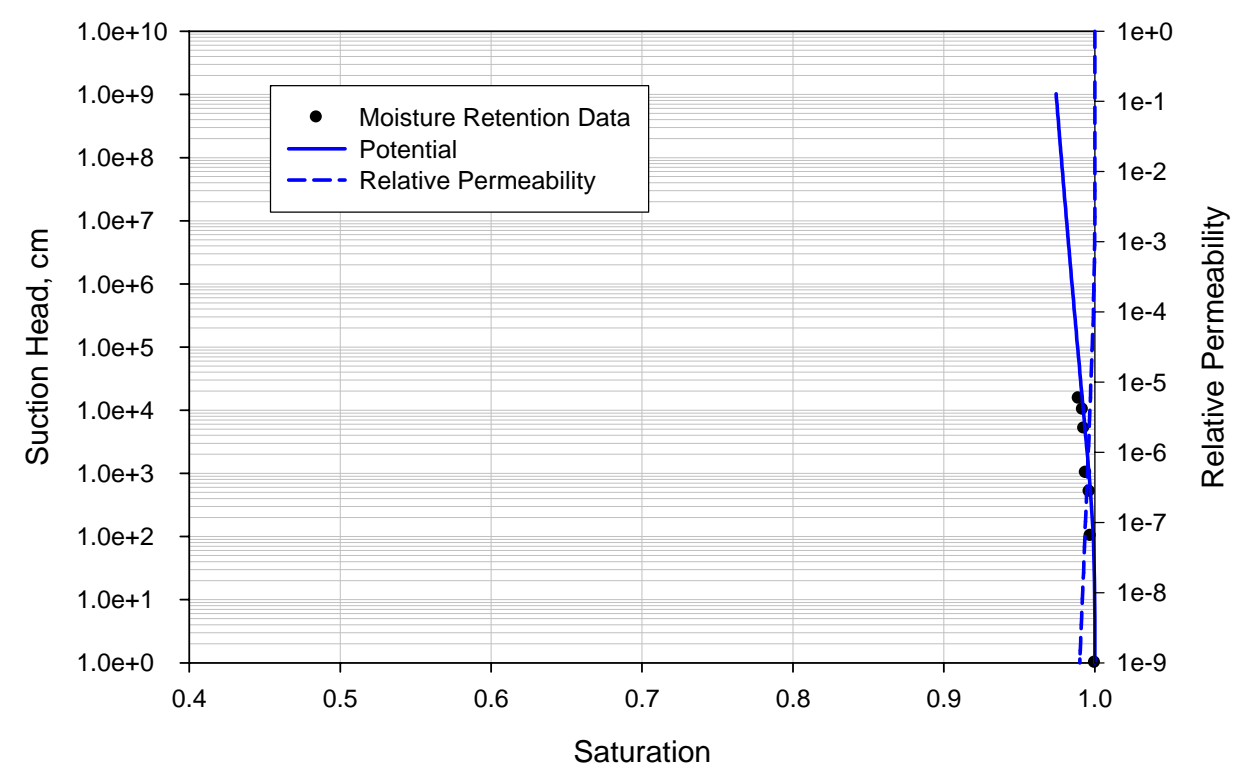

Figure 3. Characteristic curves for MCU saltstone sample SLT004B.

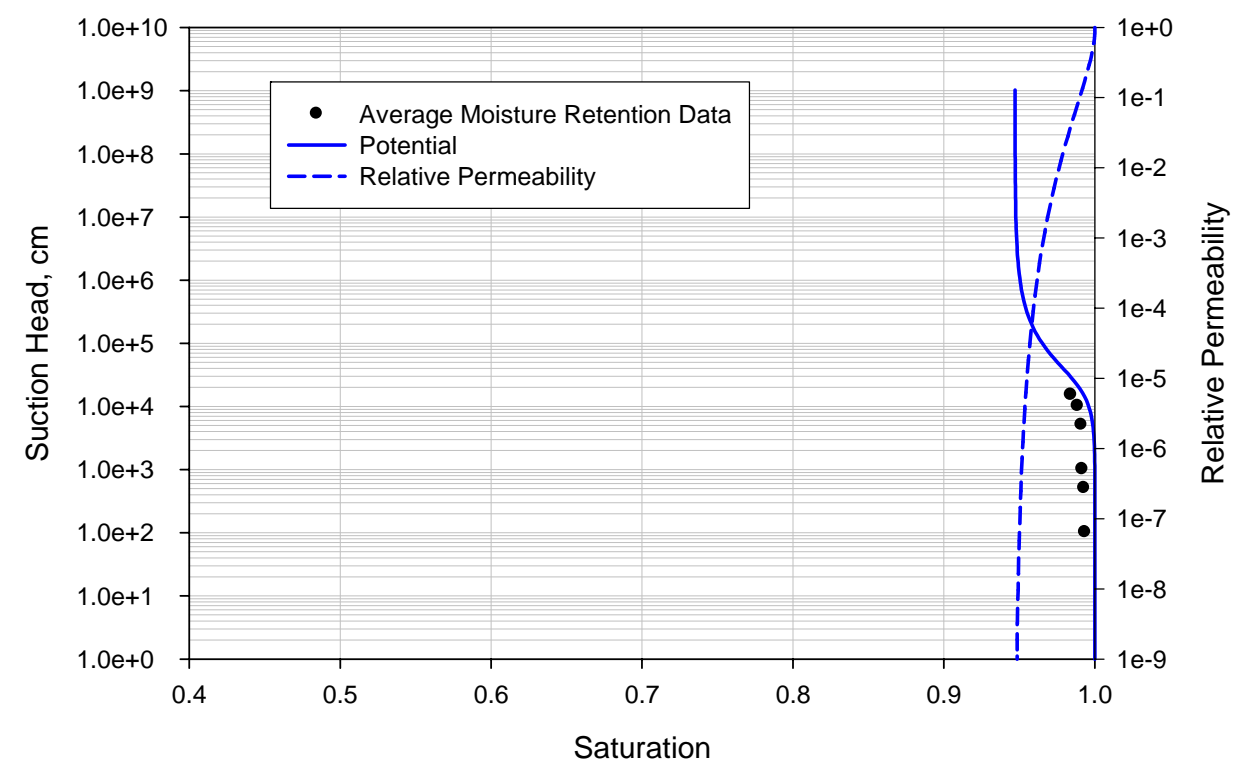

Figure 4. Average characteristic curves for MCU saltstone (SLT003B and SLT004B). 
WSRC-STI-2007-00649, REVISION 0

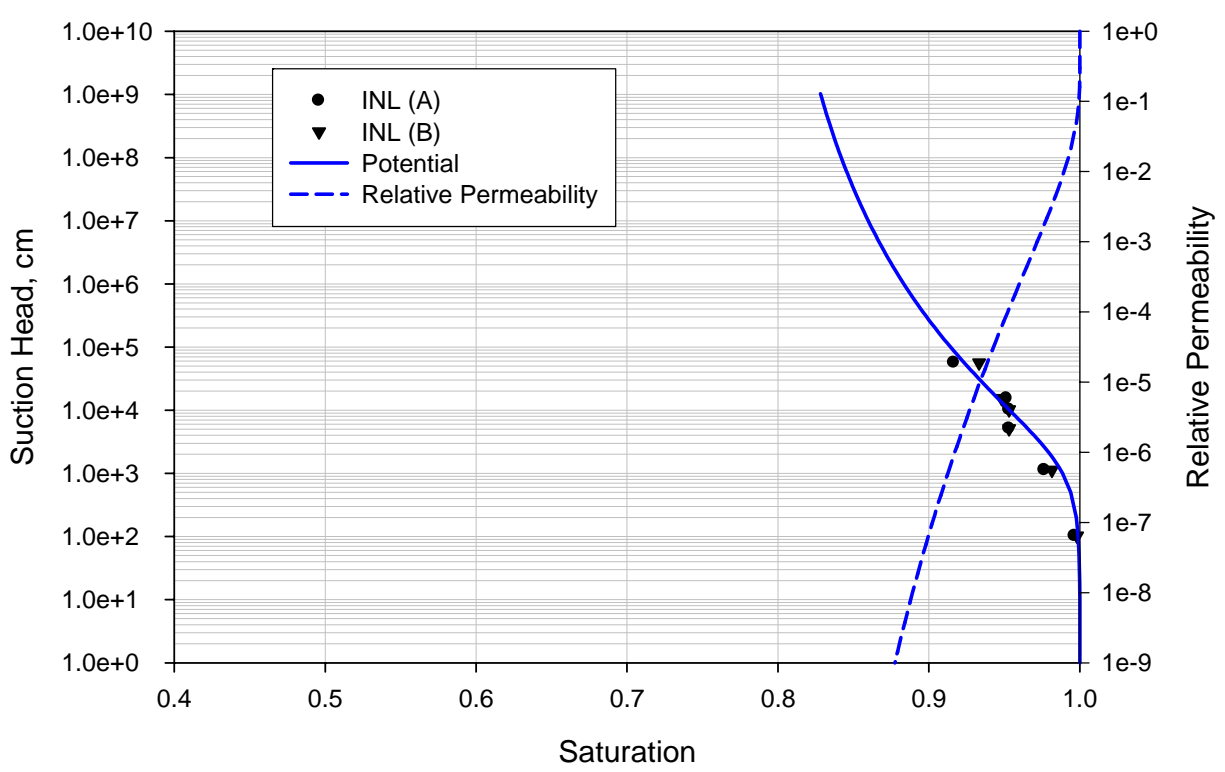

Figure 5. Characteristic curves for MCU saltstone samples as determined by INL. 
Table 1. Saltstone Cementitious Materials ${ }^{1}$.

\begin{tabular}{|l|c|}
\hline \multicolumn{1}{|c|}{ Ingredient } & $\begin{array}{c}\text { Premix Blend } \\
\text { (wt\%) }\end{array}$ \\
\hline Portland Cement (type II) & 0.10 \\
\hline Fly Ash (class F) & 0.45 \\
\hline Blast Furnace Slag (grade 100) & 0.45 \\
\hline
\end{tabular}

${ }^{1} \mathrm{~A}$ water to premix ratio of 0.6 was used for each batch.

Table 2. Recipe for MCU Simulant used to Prepare MCU Saltstone Samples.

\begin{tabular}{|c|c|c|}
\hline $\begin{array}{r}\text { Ingredient } \\
\end{array}$ & $\begin{array}{c}\text { Molarity } \\
\text { (Moles/Liter) }\end{array}$ & $\begin{array}{c}\text { Mass } \\
\left.\text { (g/Liter } \mathrm{H}_{2} \mathrm{O}\right)\end{array}$ \\
\hline Sodium Hydroxide, $\mathrm{NaOH}$ (50 \% by weight) & 1.59 & 127.50 \\
\hline Sodium Nitrate, $\mathrm{NaNO}_{3}$ & 3.16 & 268.48 \\
\hline Sodium Nitrite, $\mathrm{NaNO}_{2}$ & 0.37 & 25.39 \\
\hline Sodium Carbonate, $\mathrm{Na}_{2} \mathrm{CO}_{3}$ & 0.18 & 18.65 \\
\hline Sodium Sulfate. $\mathrm{Na}_{2} \mathrm{SO}_{4}$ & 0.06 & 8.37 \\
\hline Aluminum Nitrate Nonahydrate, $\mathrm{Al}\left(\mathrm{NO}_{3}\right)_{3}\left(9 \mathrm{H}_{2} \mathrm{O}\right)$ & 0.05 & 20.33 \\
\hline Trisodium Phosphate Dodecahydrate, $\mathrm{Na}_{3} \mathrm{PO}_{4}\left(12 \mathrm{H}_{2} \mathrm{O}\right)$ & 0.01 & 4.40 \\
\hline
\end{tabular}

Table 3. Recipe for Simulated Saltstone Pore Fluid and Simulated Groundwater Equilibrated with Vault Concrete.

\begin{tabular}{|l|c|c|}
\hline Ingredient & $\begin{array}{c}\text { Saltstone Pore } \\
\text { Fluid Simulant }\end{array}$ & $\begin{array}{c}\text { Equilibrated } \\
\text { Groundwater } \\
\text { Simulant }\end{array}$ \\
\hline Deionized water & $1000 \mathrm{~g}$ & $1000 \mathrm{~g}$ \\
\hline Sodium Nitrate, $\mathrm{NaNO}_{3}$ & $272.0 \mathrm{~g}$ & NA \\
\hline Sodium Chloride, $\mathrm{NaCl}$ & $53.1 \mathrm{~g}$ & NA \\
\hline Sodium Hydroxide, $\mathrm{NaOH}$ & $24.0 \mathrm{~g}$ & $\mathrm{NA}$ \\
\hline Calcium Hydroxide, $\mathrm{Ca}(\mathrm{OH})_{2}$ & NA & $1.5 \mathrm{~g}$ \\
\hline
\end{tabular}

${ }^{1}$ Weigh out salts. Combine with 1000 g water. Mixing of the solution should be done under a nitrogen (or other CO2-free) atmosphere. The solution should be stored in a tightly capped bottle with a minimum of head space.

${ }^{2}$ Groundwater simulant is representative of groundwater equilibrated with concrete.

${ }^{3}$ Titrate with either $\mathrm{NaOH}$ or $\mathrm{HCl}$ to achieve a $\mathrm{pH}$ of 12.4. Prepare and store the solution in the absence of $\mathrm{CO}_{2}$. 
Table 4. Hydraulic Properties of MCU Saltstone as Measured by GTX (28 day minimum curing period).

\begin{tabular}{|c|c|c|c|}
\hline & & & \\
Sample Id & Sample Type & $\begin{array}{c}\text { Permeating } \\
\text { Solution }^{1}\end{array}$ & $\begin{array}{c}\text { Saturated Hydraulic } \\
\text { Conductivity (cm/s) }\end{array}$ \\
\hline SLT003 & 3" Mold & $\mathrm{Ca}(\mathrm{OH})_{2}$ & $1.5 \mathrm{E}-08$ \\
\hline SLT004 & 3" Mold & $\mathrm{NaOH}$ & $5.3 \mathrm{E}-09$ \\
\hline
\end{tabular}

${ }^{1}$ Two permeating solutions were used: groundwater equilibrated with vault concrete $\left(\mathrm{Ca}(\mathrm{OH})_{2}\right)$ and simulated saltstone pore fluid $(\mathrm{NaOH})$.

Table 5. Physical Properties of MCU Saltstone as Measured by GTX (28 day minimum curing period).

\begin{tabular}{|c|c|c|c|c|}
\hline Sample Id & $\begin{array}{c}\text { Sample } \\
\text { Type } \\
\end{array}$ & $\begin{array}{l}\text { Particle } \\
\text { Density } \\
\left(\mathrm{g} / \mathrm{cm}^{3}\right)\end{array}$ & $\begin{array}{c}\text { Dry Bulk } \\
\text { Density } \\
\left(\mathrm{g} / \mathbf{c m}^{3}\right)^{1}\end{array}$ & Porosity $^{2}$ \\
\hline SLT003 & 3" Mold & 2.45 & 0.95 & 0.613 \\
\hline SLT004 & 3" Mold & 2.48 & 0.98 & 0.600 \\
\hline
\end{tabular}

${ }^{1}$ Dry bulk density corrected for salt precipitation as described in Section 3.2.1.

${ }^{2}$ Porosity corrected for salt precipitation as described in Section 3.2.1. 
Table 6. Hydraulic Properties of MCU Saltstone as Measured by INL (28 day minimum curing period).

\begin{tabular}{|c|c|c|c|c|c|}
\hline Sample Id & $\begin{array}{c}\text { Sample } \\
\text { Type }\end{array}$ & $\begin{array}{c}\text { Permeating } \\
\text { Solution }^{1}\end{array}$ & $\begin{array}{c}\text { Permeameter } \\
\text { Saturated } \\
\text { Hydraulic } \\
\text { Conductivity } \\
(\mathrm{cm} / \mathrm{s})\end{array}$ & $\begin{array}{c}\text { UFA } \\
\text { Centrifuge } \\
\text { Hydraulic } \\
\text { Conductivity } \\
(\mathrm{cm} / \mathrm{s}) \\
\end{array}$ & $\begin{array}{c}\begin{array}{c}\text { Average } \\
\text { Hydraulic } \\
\text { Conductivity } \\
(\mathbf{c m} /)^{3}\end{array} \\
\end{array}$ \\
\hline SLT231-A & $\begin{array}{c}\text { 1" } \\
\text { Mold }\end{array}$ & $\mathrm{NaOH}$ & $6.0 \mathrm{E}-09$ & $3.0 \mathrm{E}-08$ & $1.8 \mathrm{E}-08$ \\
\hline SLT231-C & $\begin{array}{c}1 " \\
\text { Mold }\end{array}$ & $\mathrm{NaOH}$ & $1.0 \mathrm{E}-08$ & $1.0 \mathrm{E}-08$ & $1.0 \mathrm{E}-08$ \\
\hline SLT231-D & $\begin{array}{c}1 " \\
\text { Mold }\end{array}$ & $\mathrm{Ca}(\mathrm{OH})_{2}$ & $3.0 \mathrm{E}-08$ & 8.0E-09 & $1.9 \mathrm{E}-08$ \\
\hline SLT231-E & $\begin{array}{c}1 " \\
\text { Mold }\end{array}$ & $\mathrm{Ca}(\mathrm{OH})_{2}$ & $9.0 \mathrm{E}-09$ & -4 & $9.0 \mathrm{E}-09$ \\
\hline
\end{tabular}

\footnotetext{
${ }^{1}$ Two permeating solutions were used: simulated saltstone pore fluid $(\mathrm{NaOH})$ and groundwater equilibrated with vault concrete $\left(\mathrm{Ca}(\mathrm{OH})_{2}\right)$

${ }^{2}$ The saturated hydraulic conductivity of the potted samples was estimated using a falling head method with 2 meters of head.

${ }^{3}$ Average of Permeameter and UFA hydraulic conductivity.

${ }^{4}$ Test invalid due to a leaky o-ring seal.
} 
WSRC-STI-2007-00649, REVISION 0

Table 7. Moisture Retention Data for MCU Saltstone (28 day minimum curing period).

\begin{tabular}{|c|c|c|c|c|c|c|c|c|c|}
\hline \multirow{6}{*}{$\begin{array}{c}\text { Sample } \\
\text { Id }\end{array}$} & \multirow[b]{6}{*}{ Location $^{1}$} & \multirow{6}{*}{$\begin{array}{c}\text { Bulk } \\
\text { Density } \\
\text { (g/cm3) }\end{array}$} & \multicolumn{7}{|c|}{ Potential } \\
\hline & & & \multicolumn{7}{|c|}{$(\mathrm{cm})$} \\
\hline & & & $\mathbf{0}$ & $\begin{array}{l}-101.97 \\
\end{array}$ & -509.87 & $-1,019.74$ & $-5,098.72$ & $-10,197.44$ & $-15,296.16$ \\
\hline & & & (0.00 bars) & $\begin{array}{l}(-0.10 \\
\text { bars) }\end{array}$ & $\begin{array}{l}(-0.50 \\
\text { bars) }\end{array}$ & (-1.0 bars) & (-5.0 bars) & (-10.0 bars) & (-15.0 bars) \\
\hline & & & \multicolumn{6}{|c|}{ Volumetric Moisture Content ${ }^{1}$} & \\
\hline & & & \multicolumn{6}{|c|}{$(\mathrm{cm} 3 / \mathrm{cm} 3)$} & \\
\hline SLT003 & Bottom & 0.97 & 0.592 & 0.586 & 0.585 & 0.585 & 0.585 & 0.583 & 0.579 \\
\hline $\begin{array}{l}\text { SLT004 } \\
\end{array}$ & Bottom & 1.06 & 0.578 & 0.577 & 0.576 & 0.575 & 0.574 & 0.574 & 0.572 \\
\hline
\end{tabular}

${ }^{1}$ Samples from the top of both SLT003 and STL004 fractured at 0.5 bar or less applied pressure.

${ }^{2}$ Dry bulk density and volumetric moisture content corrected as described in Section 3.2.1.

Table 8. Moisture Retention Properties of the MCU Saltstone as measured by INL (28 day minimum curing period).

\begin{tabular}{|c|c|c|c|c|c|c|}
\hline \multirow[b]{2}{*}{ Method } & \multicolumn{3}{|c|}{ Simulated Saltstone Pore Fluid Samples } & \multicolumn{3}{|c|}{ Groundwater Equilibrated with Vault Concrete Samples } \\
\hline & $\begin{array}{c}\text { Potential } \\
\text { (cm) }\end{array}$ & $\begin{array}{c}\text { Volumetric } \\
\text { Moisture Content }{ }^{1} \\
\left(\mathrm{~cm}^{3} / \mathrm{cm}^{3}\right) \\
\end{array}$ & $\begin{array}{c}\text { Average } \\
\text { Bulk Density } \\
\left(\mathrm{g} / \mathrm{cm}^{3}\right) \\
\end{array}$ & $\begin{array}{c}\text { Potential } \\
(\mathrm{cm})\end{array}$ & $\begin{array}{c}\text { Volumetric } \\
\text { Moisture Content }{ }^{1} \\
\left(\mathrm{~cm}^{3} / \mathrm{cm}^{3}\right) \\
\end{array}$ & $\begin{array}{c}\text { Average } \\
\text { Bulk Density } \\
\left(\mathrm{g} / \mathrm{cm}^{3}\right) \\
\end{array}$ \\
\hline Hanging Column $^{2}$ & 101.97 & 0.698 & 0.699 & 101.97 & 0.697 & 0.724 \\
\hline Pressure Plate $^{2}$ & 1121.72 & 0.687 & 0.734 & 1121.72 & 0.683 & 0.744 \\
\hline Pressure Plate $^{2}$ & 5098.72 & 0.667 & - & 5098.72 & 0.667 & - \\
\hline Pressure Plate $^{2}$ & 10197.44 & 0.667 & - & 10197.44 & 0.667 & - \\
\hline Pressure Plate $^{2}$ & 15296.16 & 0.663 & - & 15296.16 & 0.666 & - \\
\hline Chilled Mirror $^{3}$ & 56085.94 & 0.653 & - & 57105.68 & 0.641 & - \\
\hline
\end{tabular}

${ }^{1}$ Dry bulk density and volumetric moisture content corrected as described in Section 3.2.1 and 3.2.2.

${ }^{2}$ Sample 1 inch in diameter by $0.8 \mathrm{~cm}$ long.

${ }^{3}$ Sample consisted of $3 \mathrm{~mm}$ diameter grains. 
Table 9. Van Genuchten Transport Parameters ${ }^{1}$.

\begin{tabular}{|c|c|c|c|c|c|c|}
\hline Analysis & $\begin{array}{c}\boldsymbol{\theta}_{\mathbf{s}} \\
\left(\mathbf{c m}^{3} / \mathbf{c m}^{-3}\right)\end{array}$ & $\begin{array}{c}\boldsymbol{\theta}_{\mathbf{r}} \\
\left(\mathbf{c m}^{3} / \mathbf{c m}^{-3}\right)\end{array}$ & $\begin{array}{c}\boldsymbol{\alpha} \\
(\mathbf{1} / \mathbf{c m})\end{array}$ & $\mathbf{n}$ & $\mathbf{m}$ & $\mathbf{r}^{\mathbf{2}}$ \\
\hline SLT003B & 0.585 & 0.550 & 0.00005 & 2.86748 & 0.33333 & 0.98 \\
\hline SLT004B & 0.578 & 0.492 & 0.00846 & 1.01189 & 0.01175 & 0.91 \\
\hline Average $^{2}$ & 0.581 & 0.550 & 0.00004 & 1.74923 & 0.42832 & 0.97 \\
\hline INL $^{3}$ & 0.700 & 0.550 & 0.00070 & 1.12000 & 0.10714 & NA \\
\hline
\end{tabular}

${ }^{1}$ Data analyzed using Mualem relationship between $\mathrm{n}$ and $\mathrm{m}$ where $\mathrm{m}=1-1 / \mathrm{n}$.

${ }^{2}$ Moisture retention data from SLT003B and SLT004B averaged for this analysis.

${ }^{3}$ INL samples. Modified analysis where output from RETC was adjusted using visual curve matching procedure to obtain better fit of moisture retention data.

Table 10. Recommended MCU Saltstone Hydraulic Parameter Values Based upon this Study

\begin{tabular}{|c|c|c|c|c|}
\hline $\begin{array}{c}\text { Saturated } \\
\text { Hydraulic } \\
\text { Conductivity } \\
(\mathrm{cm} / \mathrm{s}) \\
\end{array}$ & $\begin{array}{c}\text { Particle Density } \\
\left(\mathrm{g} / \mathrm{cm}^{3}\right)\end{array}$ & $\begin{array}{c}\text { Dry Bulk Density } \\
{ }_{2}\left(\mathrm{~g} / \mathrm{cm}^{3}\right)\end{array}$ & Porosity $^{3}$ & $\begin{array}{c}\text { Van Genuchten } \\
\text { Transport } \\
\text { Parameters }\end{array}$ \\
\hline $1.0 \mathrm{E}-08$ & 2.45 & 0.99 & 0.596 & $\begin{array}{c}\text { See Average from } \\
\text { Table } 9\end{array}$ \\
\hline
\end{tabular}

${ }^{1}$ Average saturated hydraulic conductivity from Table 4

${ }^{2}$ Average dry bulk density from Tables 5 and 7

${ }^{3}$ Average porosity from Tables 5 and 7

${ }^{4}$ Calculated: Particle density $=$ dry bulk density $/(1-$ porosity $)$ 
WSRC-STI-2007-00649, REVISION 0

APPENDIX A. LABORATORY NOTEBOOK PAGES FROM MCU SALTSTONE SAMPLE PREPARATION 


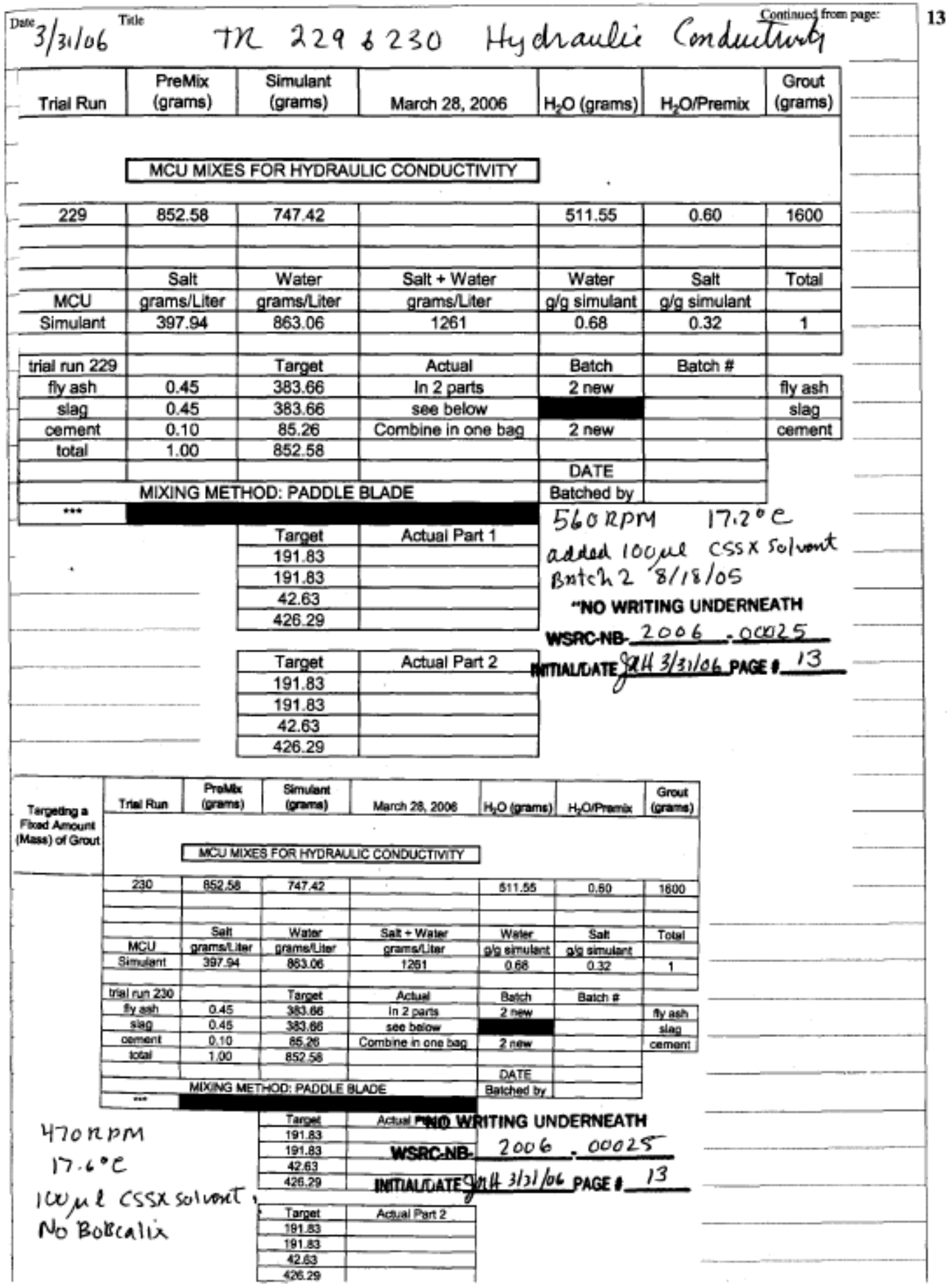


14

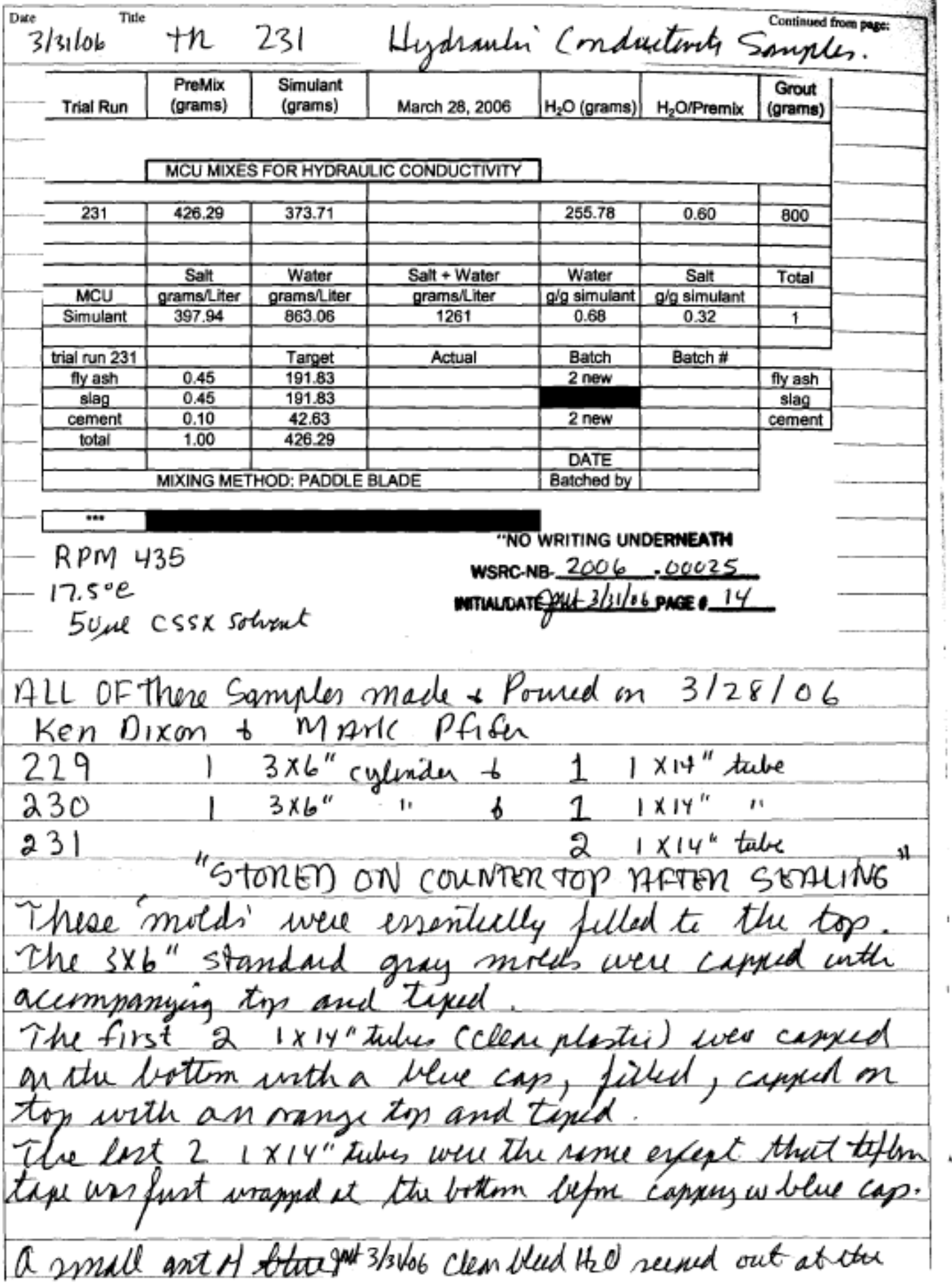




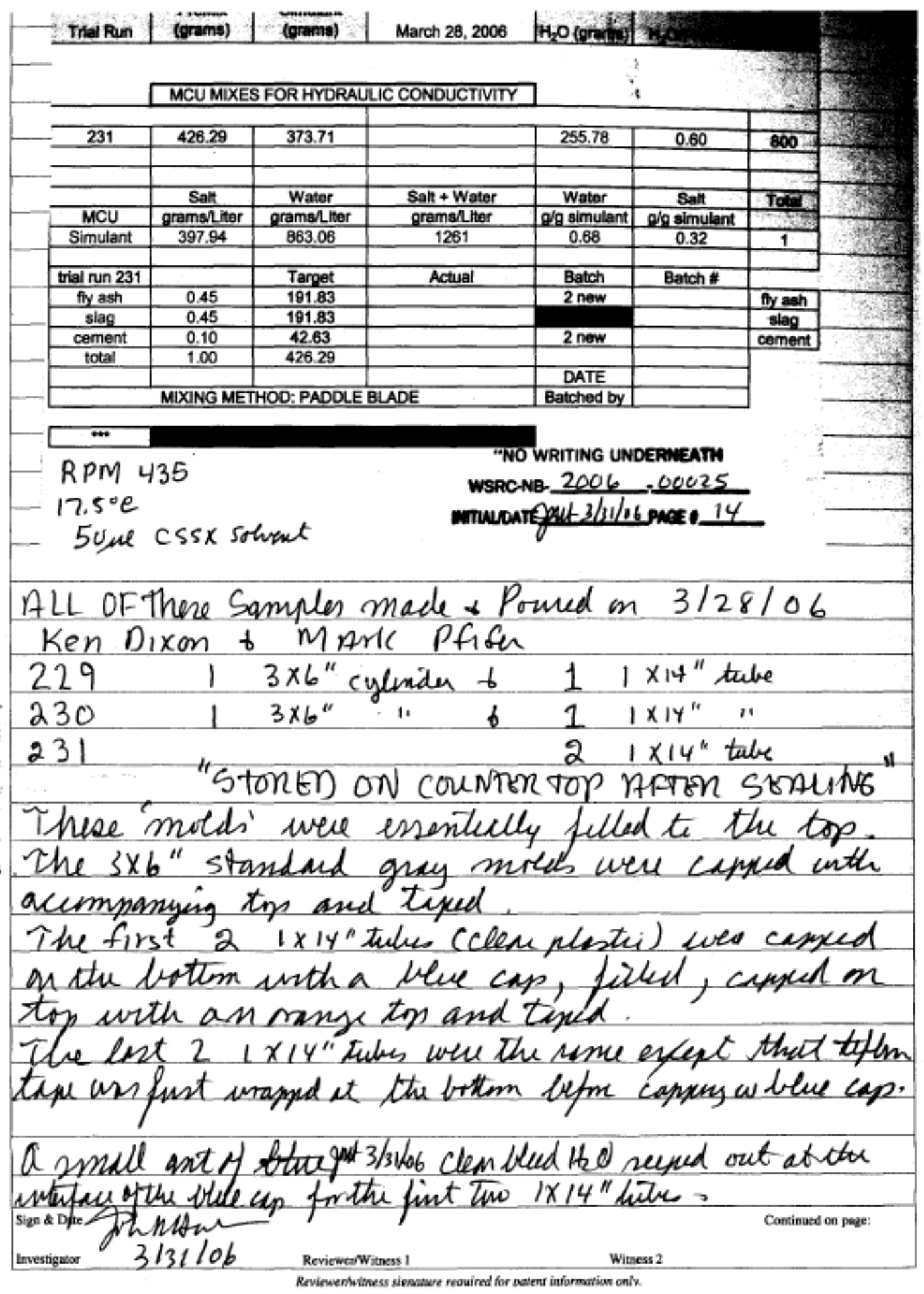


WSRC-STI-2007-00649, REVISION 0

\section{APPENDIX B. RECIPES FOR SALTSTONE PORE FLUID AND GROUNDWATER EQUILIBRATED WITH CONCRETE}


WSRC-STI-2007-00649, REVISION 0

Recipe for Saltstone Pore Fluid

$\begin{array}{ll}\text { Miles Denham/SRNL/Srs } & \text { To Mark Phifer/SRNU/Srs@Srs, Kenneth Dixon/SRNL/Srs@srs } \\ 05 / 16 / 200602: 22 \mathrm{PM} & c c \\ \text { bcc } & \text { Subject Recipe for Saltstone Porewater }\end{array}$

Into 1 liter of DI water add:

24.0 grams $\mathrm{NaOH}$

53.1 grams $\mathrm{NaCl}$

272.0 grams $\mathrm{NaNO} 3$

Adjust pH to 13.8 using either $\mathrm{NaOH}$ or $\mathrm{HNO} 3$.

If at all possible, mixing of the solution should be done under a nitrogen (or other $\mathrm{CO} 2$-free) atmosphere. The solution will dissolve a lot of $\mathrm{CO} 2$ that will lower the $\mathrm{pH}$. More importantly, if there is carbonate in the solution it can react with calcium hydroxide in the cement and cause precipitation of calcite.

The solution should be stored in a tightly capped bottle with a minimum of head space. 
WSRC-STI-2007-00649, REVISION 0

\section{Recipe for Groundwater Equilibrated With Concrete}

Miles Denham/SRNL/Srs

04/07/2006 10:35 AM
To Mark Phifer/SRNUSrs@Srs, Kenneth Dixon/SRNL/Srs@srs

$\mathrm{cc}$

$b c 0$

Subject Re: 1993 Permeant Vs Current Recommended Permeant]

Mark and Ken,

I have compared the two brine recipes for the Saltstone experiments. The 1993 permeant is more concentrated than the recipe I provided. It is saturated with $\mathrm{NaNO}$, so small changes in chemistry induced by contacting the saltstone minerals could cause significant precipitation. For example, if $1 \%$ of the water was lost from this solution to mineral hydration, up to $29 \mathrm{~cm} 3$ of NaNO3 could precipitate per liter. The recipe I provided earlier yields a brine that is saturated with portlandite $(\mathrm{Ca}(\mathrm{OH}) 2)$, but small chemical changes will not cause significant precipitation because the calcium concentration is so low. For example, loss of $1 \%$ of the water in the solution would result in up to $0.003 \mathrm{~cm} 3$ of portlandite precipitation.

I also equilibrated a groundwater composition with the vault cement composition reported in WSRC-TR-2006-00035 (my previous saltstone report). I used a groundwater analysis for well P-16B from Strom and Kaback (1992) and assumed that it was initially at equilibrium with atmospheric CO2, but was isolated from the atmosphere during reaction with the cement. If the reaction were open to atmosphere all of the cement would become completely carbonated during the reaction and large amounts of calcite would precipitate. The equilibrated composition is:

$\begin{array}{ll}\mathrm{pH} & 12.4 \\ \mathrm{Ca} & 0.016 \\ \mathrm{Na} & 3.0 \mathrm{e}-5 \\ \mathrm{SO} 4 & 4.8 \mathrm{e}-5 \\ \mathrm{Cl} & 6.8 \mathrm{e}-5\end{array}$

Thus, it is essentially a calcium hydroxide solution. $\mathrm{CO} 2$ is a problem with these experiments. Ideally, they would be done in a $\mathrm{CO} 2$-free atmosphere. This is unlikely to be the case, so there is a possibility of calcite precipitation during the experiments that could affect permeability. However, this might simulate reality better than the case where there is no interaction of the fluid with cement phases. It would be very cool if they could do an experiment with this fluid and one with a nonpolar water insoluble organic liquid. Then. we would have a permeability of a solution that is representative of what will actually occur and a permeability of a fluid in which we know there is no precipitation or dissolution.

Anyway the recipe for the above solution is:

1.5 grams $\mathrm{Ca}(\mathrm{OH}) 2$ in 1 kilogram of water. Titrate with either $\mathrm{NaOH}$ or $\mathrm{HCl}$ to achieve a pH of 12.4 .

This should all be done taking care to minimize the exposure of the solution to air. A tiny amount of calcite may precipitate (the calculations suggest about $1 \mathrm{mg}$ ). Much more will precipitate if the solution reacts with air. In addition, the pH will go down. Hence the need to prepare the solution and store it in the absence of $\mathrm{CO} 2$.

We may want to talk about it prior to the experiments.

Miles

Mark Phifer/SRNL/Srs

Mark Phifer/SRNL/Srs 
WSRC-STI-2007-00649, REVISION 0

\section{APPENDIX C. INL REPORT ON TESTING OF MCU SALTSTONE}


WSRC-STI-2007-00649, REVISION 0

baho Nctional lobordocy

October 9,2006

$\mathrm{CCN} 207262$

Kenneth L. Dixon

Savannah River National Laboratory

Building 773-42A

Aiken, SC 29808

SUBJECT: Data Report for Savannah River Site - Saltstone cores (INL/MIS-06-11865)

Dear Kenneth:

Scope

Provide testing and consulting services for saltstone samples.

\section{Introduction}

Three saltstone cores identified as 229,230 and 231 were received for hydraulic analyses from the Savannah River Site (SRS). The cores were casts of saltstone material that was cured in polybutyrate plastic tubes. The tubes had dimensions of approximately $2.5 \mathrm{~cm}$ diameter by $-30 \mathrm{~cm}$ long. All cores were received in good shape with no visual fracturing or significant drying noted upon receipt.

Requested analysis included dry bulk density, porosity, moisture retention characteristics, saturated and unsaturated hydraulic conductivity measurements, and "van Genuchten" parameters. To expedite the analyses, separate sub-cores were used to complete the analyses.

Two testing solutions were used for the hydraulic analyses. The first solution followed a recipe to simulate saltstone porewater. This solution consisted of:

$$
\begin{aligned}
& 24.0 \mathrm{~g} \mathrm{NaOH} \\
& 53.1 \mathrm{~g} \mathrm{NaCl} \\
& 272.0 \mathrm{~g} \mathrm{NaNO}_{3} \\
& 1 \mathrm{I} \text { nanopure } \mathrm{H}_{2} \mathrm{O} .
\end{aligned}
$$

The $\mathrm{pH}$ was verified and the solution was stored in a volumetric flask with a glass stopper, and sealed with a parafilm wrap. In this report, this solution is referred to as the $\mathrm{NaOH}$ solution.

The second solution was a mixture to simulate groundwater in equilibrium with the vault cement composition. The recipe for this solution was:

$1.5 \mathrm{~g} \mathrm{Ca}(\mathrm{OH})_{2}$ mix in $1 \mathrm{~kg}$ nanopure water.

P.O. Box 1625 - 2525 North Fremont Ave. • Idaho Falls, Idaho 83415 * 208-526-0111 • www.inl.gov Battelle Energy Alliance, LC 
WSRC-STI-2007-00649, REVISION 0

Kenneth L. Dixon

October 9,2006

CCN 207262

Page 2

The $\mathrm{pH}$ was verified and this solution was also stored in volumetric flask with a glass stopper to minimize head space and sealed with parafilm wrap during storage. In this report, this solution is referred to as the $\mathrm{Ca}(\mathrm{OH})_{2}$ solution.

\section{Sample Preparation}

From the $30 \mathrm{~cm}$ long saltstone cores, sub-cores were cut using a masonry saw. The first set of sub-cores was used for permeability analysis using both the standard falling head and the centrifuge methods. The second set of sub-cores was used to determine the moisture characteristics (plus bulk density and porosity) of the saltstone material. Due to the unique chemical and physical nature of the saltstone, a number of problems developed during sample preparation and testing resulting in numerous modifications to the standard sample preparation procedure.

Sub-cores used in the permeability analysis required potting these samples in an epoxy mixture to establish a no flow boundary along the length of the sub-core and provide a uniform outer diameter for hydraulic conductivity testing (Figure 1). In general, the length of the permeability sub-core was initially cut to $6 \mathrm{~cm}$ in length to facilitate potting the core in our UFA mold. The cores were centered in the $3.3 \mathrm{~cm}$ diameter Teflon mold, and filled with a two part epoxy molding compound. After curing ( $\sim 24$ to 48 hours), the mold was split open to extract the potted cement material. The ends of the potted material were then trimmed to a length appropriate for the UFA using a masonry saw $(\sim 5 \mathrm{~cm}$ in length).

Four attempts to pot these saltstone cores were made to rectify physical and chemical problems. During our first attempt to pot the sub-core samples, we left the plastic sleeve on the sub-cores then after a light sanding of the exterior of the plastic, potted the whole assembly (ie. the core and the plastic sleeve) in the mold. During the vacuum saturation of these sub-cores gas bubbles were observed between the plastic sleeve and the saltstone indicating that the saltstone material did not make a tight seal with the plastic liner material after it was cured. To rectify this problem, during our second attempt, we removed the plastic liner from the salt stone material and attempted to pot the saltstone directly to the epoxy. We had questionable success using this technique with the saltstone samples. After the epoxy cured, we noted a potential chemical reaction had take place between the moist saltstone and the epoxy. Saltstone porewater is believed to be at a $\mathrm{pH}$ of about 13.4. Our typical potting epoxy contains aluminum and we believe that the $\mathrm{NaOH}$ in the saltstone porewater reacted with the aluminum in the epoxy as the epoxy was setting. In some areas next to the saltsone, the epoxy did not appear to set to the same consistency as is typically noted. We discuss numerous epoxy chemistry's with epoxy manufactures and ordered a new potting compound the contained ceramic instead of the aluminum in the formula. The ceramic epoxy is a "paintable" epoxy and is typically used to protect metals from conrosive liquids. For our third attempt, we first removed the plastic sleeve from the saltstone, then coated the core with the ceramic epoxy, let dry and then potted the coated saltstone core with the aluminum epoxy. The initial chemical compatibility coating of the saltstone with the ceramic epoxy appeared to be an appropriate solution for potting the saltstone. Although the third attempt was successful, the last pair of cores was simply potted in our mold solely using ceramic epoxy. The ceramic epoxy is typically not used as a casting compound 
Kenneth L. Dixon

October 9, 2006

CCN 207262

Page 3

but, in our case, the volume of ceramic epoxy required for each mold was small enough such that heat generation was not an issue.

Potting the sub-cores into epoxy was not necessary for dry bulk density, porosity and moisture characteristic measurements. These subcores were also cut from the $30 \mathrm{~cm}$ saltstone samples and we initially retained the plastic sleeve on the outside of the sub-cores. During testing, we removed these sleeves after poor binding of the saltstone material to the plastic sleeve material was noted as described above. Sample lengths were approximately $1 \mathrm{~cm}$ height. To expedite testing, separate sub-cores were used to determine various portions of the moisture retention curve.

Due to a limited amount of sample that was initially shipped and to the physical and geochemical compatibility problems of potting the saltstone, there was not sufficient sample material to perform all analysis on a single sample. Moisture characteristics characterization was performed on sample mumbers' 229 and 230, where as hydraulic analysis was performed on sample number 231 .

The alkaline solutions prepared are subject to $\mathrm{pH}$ changes with exposure to air. Care was taken to minimize contact of both the solutions and the samples that were permeated with these solutions with the open atmosphere. Some exposure to air was unavoidable when measuring weights and transferring samples between testing apparatus. While the saltstone samples were in testing apparatus, $\mathrm{CO}_{2}$ traps were employed. The $\mathrm{CO}_{2}$ traps consisted of a concentrated $\mathrm{NaOH}$ solution either as bubble traps or in containers with high surface area. Permeameter testing used bubble traps (similar to a Marriott bottle) connected to the permeameter standpipes to strip any $\mathrm{CO}_{2}$ from entering the head space of the standpipe. Bubble traps were not appropriate for the vacuum saturation, hanging column, and pressure plate equipment. During these tests, we placed shallow pans of $\mathrm{NaOH}$ on top of the samples (similar to systems used to look at long-term respiration of soil) in an attempt to minimize atmospheric $\mathrm{CO}_{2}$ interaction with the samples.

\section{Methods}

Dry bulk density is expressed as the mass per unit volume of material. Procedures followed those described in Method of Soil Analysis where the total volume of a porous material is measured, then dried in an oven at 105 degrees $C$ to determine the dry porous material mass. For the saltstone subcores, the diameter and length of each sub-core was measured with a caliper to determine its volume. 
Kenneth L. Dixon

October 9, 2006

CCN 207262

Page 4

The sub-cores were dried in an oven for at least 24 to 48 hours to a constant weight. Dividing the mass by its volume gives its bulk density. Sub-core samples from the hanging column and the pressure plate analyses were used to calculate an average bulk density.

Vacuum saturation was performed following procedures described by Flint and Flint (Method of Soil Analysis, chapter 2.3, pg 233). No pre-flushing with $\mathrm{CO}_{2}$ was performed. A plastic desiccant chamber was used at the vacuum chamber and the two alkaline solutions were used as permeate fluids. Vacuum saturation lasted approximately 6 days.

Saturated water porosity can be determined by either directly or can be calculated as a fitting parameter from the van Genuchten analysis of the moisture retention data. Typically, the weight of the samples immediately at the termination of the falling head method was used to calculate the saturated water porosity. For the saltstone samples, determination of the saturated water porosity was not consistent with the moisture characteristic analyses and therefore not used. See discussion of potential issues in the result section. For these analyses, we will use the fitted saturated hydraulic conductivity value from the van Genuchten analyses.

Saturated hydraulic conductivity measurements were preformed on the potted sub-cores after vacuum saturation. After vacuum saturation, the sub-cores were analyzed using the falling head method outlined in ASTM D6527 and those described by Reynolds and Elrick in Methods of Soil Analysis, Chapter 3.4.2.3 and used the two solutions requested by SRNL personnel. Due to the low conductivity of the sub-cores these tests were run over a period of 10 to 20 days.

Saturated hydraulic conductivities were also determined using the falling head method in the UFA following the methods of Nimmo et.al.; MOSA pg 903). This testing is similar to those described in the previous paragraph but increases the fluid driving force through the sample using the centrifuge. These tests were conducted to confirm the standard falling head results as well as to provide guidance on setting the flow rate during UFA unsaturated permeability testing.

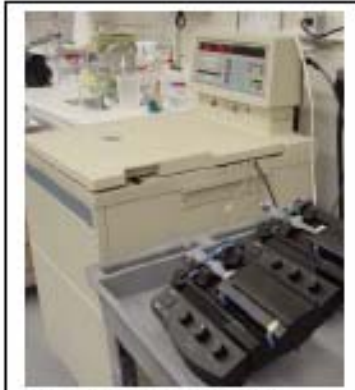

Figure 2. INL's UFA centrifuge and pumps.

Unsaturated hydraulic conductivity testing was performed in the Unsaturated Flow Apparatus (UFA) model J-6 (Figure 2). Nimmo discusses the steady state centrifuge method in Methods of Soil Analysis, Chapter 3.6.1.1.b and methods generally followed those outlined in ASTM D6527. A maximum of two sub-cores are able to be analyzed at a single time due to the design of the fluid rotary joint. A dispersion cap was placed on each potted samples and screwed into the UFA sampler holders. A pre-weighed effluent cup was attached to collect effluent in flight. The samples were spun at 500 to $3000 \mathrm{RPM}$ in the UFA centrifuge at a flux rate $(\mathrm{ml} / \mathrm{hr})$ approximately $\mathrm{s} / 2$ of that measured saturated hydraulic conductivity for each saltstone sample. Flux was supplied to the top of the samples using Orion syringe pumps. 
WSRC-STI-2007-00649, REVISION 0

Kenneth L. Dixon

October 9,2006

CCN 207262

Page 5

Moisture retention characteristics measurements describe a porous media pore size distribution through relating the amount of water retained by a porous media at known matric potentials. The data for the saltstone sub-cores were carried out by 3 separate methods.

To obtain data near saturation, we used the hanging column apparatus. Saturated samples were placed in contact with a highly porous ceramic plate that is connected to a water column and reservoir where the water surface is beneath the sample. (see MOSA pg 146). The distance between the water surface and the sample is the imposed suction on the sample (i.e. the matric potential). A series step consisting of lowering the level of the reservoir and measuring the equilibrium weight of the sample are conducted.

For the mid-matric potentials, we used the pressure plate method (Method of Soil Analysis, 2002, chapter 3.3.2.4) in a Soil Moisture 15 bar pressure plate extractor (model 1500). Saltstone sample weights were recorded on small $\sim 1 \mathrm{~cm}$ high sub-cores at $0.6,1.1,5,10$ and 15 bars of pressure. Moisture contents were calculated from the oven dried weights measured at the end of the test.

Moisture contents at higher soil water potentials ( $~-55$ bars) were measured using the chilled mirror method (Method of Soil Analysis, 2002, chapter 3.3.2.9.b) using the WP4 meter. Samples from the pressure plate method were used for these analyses. After the completion of the 15 bar pressure plate measurements, the samples were placed in the WP4 sample chamber an allowed to evaporate until there is equilibrium between the sample humidity and the matric potential of the saltstone. The humidity is then measured using the WP4 chilled mirror humidity sensor to determine the equivalent matric potential and the sample is weighted to determine its corresponding moisture content. The temperature of the WP4 mirror is controlled by a thermoelectric (Peltier) cooler. Detection of the exact point at which condensation first appears on the mirror is observed with a photoelectric beam

Hydraulic transport parameters (van Genuchten parameters alpha, $\mathrm{n}$ and saturated moisture content) were fitted to the moisture retention data. Data was analyzed using the RETC fitting program. Saturated moisture content was allowed to be fitted parameters.

\section{Results and Discussion}

Despite the sample preparation issues, the results appear to be reasonable and generally consistent with one another. The following tables and paragraph list the measurement results and provide a general discussion of the results.

\section{Bulk Density}

The dry bulk densities ranged from 1.03 to $1.06 \mathrm{~g} \mathrm{~cm}^{-3}$. The sample geometries were small and not perfectly round or cut perfectly parallel, resulting in some uncertainty of the volume calculation for bulk density analysis but it is not believe to be significant. The bulk densities for the hanging column are 
WSRC-STI-2007-00649, REVISION 0

Kenneth L. Dixon

October 9, 2006

CCN 207262

Page 6

slightly less $(\sim$ by $2 \%$ ) than those calculated from the pressure plate analyses. This trend may be due to the location of the sub-cores that were extracted from the $30 \mathrm{~cm}$ samples. The average bulk density for all sub-cores is $1.048 \mathrm{~g} \mathrm{~cm}^{-3}\left(65.4 \mathrm{lbs} \mathrm{ft}^{-3}\right)$.

\begin{tabular}{|l|l|l|}
\hline Apparatus & $\begin{array}{l}\text { Permeation } \\
\text { Solution }\end{array}$ & $\begin{array}{l}\text { Average bulk } \\
\text { density }\left(\mathrm{g} \mathrm{cm}^{-3}\right)\end{array}$ \\
\hline $\begin{array}{l}\text { Hanging } \\
\text { Column }\end{array}$ & $\mathrm{NaOH}$ & 1.047 \\
\hline $\begin{array}{l}\text { Hanging } \\
\text { Column }\end{array}$ & $\mathrm{Ca}(\mathrm{OH})_{2}$ & 1.033 \\
\hline Pressure Plate & $\mathrm{NaOH}$ & 1.058 \\
\hline Pressure Plate & $\mathrm{Ca}(\mathrm{OH})_{2}$ & 1.051 \\
\hline & & Avg $=1.048$ \\
\hline
\end{tabular}

Saturated Moisture Content

Saturated moisture contents were not calculated due to biases imposed by the retaining the polybutyrate plastic liner on the sample during saturation testing. Visual and physical inspection did not reveal any issues with the plastic liners prior to testing. However, during vacuum saturation and hanging column analysis, air and solutions were noted to flow preferentially between the saltstone and plastic liner. Analysis of the saturated moisture content indicated a bias in the data (high at $\sim 65-70 \%$ ) when the samples were analyzed with the plastic liner still attached. Either the plastic walls are too smooth and prevented the saltstone of making a good physical contact with the polybutyrate plastic or there was a slight amount of shrinkage of the saltstone material during curing. To avoid confusion, moisture content data from samples with the plastic liner still attached are not reported in this letter report. The fitted saturated moisture content from the van Genuchten analyses is 0.60 .

Moisture Retention Data

Both the saltstone sub-cores permeated with the $\mathrm{NaOH}$ and the $\mathrm{Ca}(\mathrm{OH})_{2}$ exhibited similar moisture characteristics suggesting that the permeating solution did not make any significant alterations to the saltstone pore structure.

\begin{tabular}{|c|c|c|c|c|}
\hline & \multicolumn{2}{|c|}{$\mathrm{NaOH}$ permeate solution } & \multicolumn{2}{|c|}{$\mathrm{Ca}(\mathrm{OH})_{2}$ permeate solution } \\
\hline Method & $\begin{array}{l}\text { Matric Potential } \\
\text { (bars) }\end{array}$ & $\begin{array}{l}\text { Moisture Content } \\
\left(\mathrm{cm}^{3} \mathrm{~cm}^{-3}\right)\end{array}$ & $\begin{array}{l}\text { Matric Potential } \\
\text { (bars) }\end{array}$ & $\begin{array}{l}\text { Moisture Content } \\
\left(\mathrm{cm}^{3} \mathrm{~cm}^{-3}\right)\end{array}$ \\
\hline $\begin{array}{l}\text { Hanging } \\
\text { Column }\end{array}$ & 0.1 & 0.599 & 0.1 & 0.598 \\
\hline Pressure Plate & 1.1 & 0.589 & 1.1 & 0.586 \\
\hline Pressure Plate & 5 & 0.572 & 5 & 0.572 \\
\hline Pressure Plate & 10 & 0.572 & 10 & 0.572 \\
\hline Pressure Plate & 15 & 0.569 & 15 & 0.571 \\
\hline Chilled Mirror & 55 & 0.560 & 56 & 0.550 \\
\hline
\end{tabular}


Kenneth L. Dixon

October 9, 2006

CCN 207262

Page 7

Data at $0 \mathrm{~cm}$ (i.e. saturated moisture content), $39 \mathrm{~cm}$, and 0.6 bar matric potential measurements were not included in the report data since these samples contained the outer plastic sleeve. The weights of these samples were abnormally high (even accounting for the weight of the plastic) and is believed to be due to preferential solution imbibition along the sleeve and the saltstone.

See the van Genuchten analysis (Figure 4) for an illustration of the data as a function of moisture content and matric potential.

Hydraulic Conductivity

Saturated hydraulic conductivity values ranged from the $6 \times 10^{-9}$ to $3 \times 10^{-8} \mathrm{~cm} \mathrm{~s}^{-1}$, with an average conductivity of $1.3 \times 10^{-8} \mathrm{~cm} \mathrm{~s}^{-1}$. In general there was no significant differences between the conductivities of the $\mathrm{NaOH}$ and the $\mathrm{Ca}(\mathrm{OH})_{2}$ permeate solutions.

\begin{tabular}{|l|l|l|l|}
\hline Method & Sample ID & Permeate Solution & Ksat $\left(\mathrm{cm} \mathrm{s}^{-1}\right)$ \\
\hline Standard Falling Head & $231-\mathrm{A}$ & $\mathrm{NaOH}$ & $6 \mathrm{E}-09$ \\
\hline Centrifuge Falling Head & $231-\mathrm{A}$ & $\mathrm{NaOH}$ & $3 \mathrm{E}-08^{*}$ \\
\hline Standard Falling Head & $231-\mathrm{C}$ & $\mathrm{NaOH}$ & $1 \mathrm{E}-08$ \\
\hline Centrifuge Falling Head & $231-\mathrm{C}$ & $\mathrm{NaOH}$ & $1 \mathrm{E}-08^{*}$ \\
\hline Standard Falling Head & $231-\mathrm{D}$ & $\mathrm{Ca}(\mathrm{OH})_{2}$ & $3 \mathrm{E}-08$ \\
\hline Centrifuge Falling Head & $231-\mathrm{D}$ & $\mathrm{Ca}(\mathrm{OH})_{2}$ & $8 \mathrm{E}-09$ \\
\hline Standard Falling Head & $231-\mathrm{E}$ & $\mathrm{Ca}(\mathrm{OH})_{2}$ & $9 \mathrm{E}-09$ \\
\hline Centrifuge Falling Head & $231-\mathrm{E}$ & $\mathrm{Ca}(\mathrm{OH})_{2}$ & $1 \mathrm{E}-07^{* *}$ \\
\hline \begin{tabular}{l} 
notes: \\
* Only one measurement \\
* Likely a leaky o-ring seal (excluded from the average calc.) \\
Average $=1.3 \mathrm{E}-08$ \\
\hline
\end{tabular}
\end{tabular}

The results of the two different methods (standard falling head and centrifuge falling head) are fairly close suggesting that either method is appropriate for the saltstone analyses. The centrifuge method is much quicker and may be the best method for future analyses.

Gas generation was noted during the hydraulic measurements. The gas generation was most notable for $\mathrm{NaOH}$ solution with limited gas generation observed when using the $\mathrm{Ca}(\mathrm{OH})_{2}$ solution. During the standard falling head tests, the gas collected in the $\%$ inch clear tygon tubing and was purged prior to determine the flux of solution entering the sample. A small amount of error in the head measurements would be introduced due the gas collection but should result in less than a $1 \%$ error in the hydraulic conductivity measurement. During the UFA saturated hydraulic conductivity analyses, only one data set had low enough gas generation to be acceptable for analysis. At the end of the other attempts, gas bubbles were noted in the inlet lines. 
Kenneth L. Dixon

October 9, 2006

CCN 207262

Page 8

Unsaturated hydraulic testing of the saltstone proved to be difficult. An assumption of the unsaturated conductivity analysis using the centrifuge method is that the centrifugal driving force is much greater that the matric potential gradient. Darcy's Law takes the following form when one replaces the gravity force with a centrifugal force:

$$
q=-K_{\text {unar }}\left(\frac{d \psi}{d r}-\rho_{\nabla} \omega^{2} r\right)
$$

when

$$
\frac{d \psi}{d r} \leq \leq \rho_{n} \omega^{2} r
$$

Darcy's Law reduces to:

$$
q \cong K_{\text {unstst }}\left(\rho_{n} \omega^{2} r\right)
$$

The finer the texture of the media (i.e. the finer the poresize) the higher speed the centrifuge must be spun to ensure that the centrifugal driving force is greater than the matric potential gradient. Saltstone has a very fine poresize (as indicated in by the little solution drainage as the matric potential increases) suggesting that the faster the centrifuge is spun the better Equation 2 will be satisfied. Equation 3 is only valid if Equation 2 is satisfied. If Equation 2 is not valid, and the data is analyzed by Equation 3, the unsaturated hydraulic conductivity will be over estimated.

Results from the UFA unsaturated hydraulic conductivity analysis indicates that we were not able to meet the requirements of minimizing the effects of the matric potential gradient. Figure 3 illustrates the calculated hydraulic conductivity values using the UFA. Calculated values are in the range of $1 \times 10^{-5}$ to $1 \times 10^{-7} \mathrm{~cm} \mathrm{~s}^{-1}$. These values are approximately 10 to 1000 times greater that the saturated hydraulic conductivity values, suggesting that the matric potential gradient is a dominant driving force of the solution flow. As the rotational speed increases (i.e. the omega increases) we are beginning to approach the saturated hydraulic conductivity values. Higher water fluxes and higher rotation speeds would be required to obtain valid unsaturated hydraulic conductivity values. 
Kenneth L. Dixon

October 9,2006

CCN 207262

Page 9

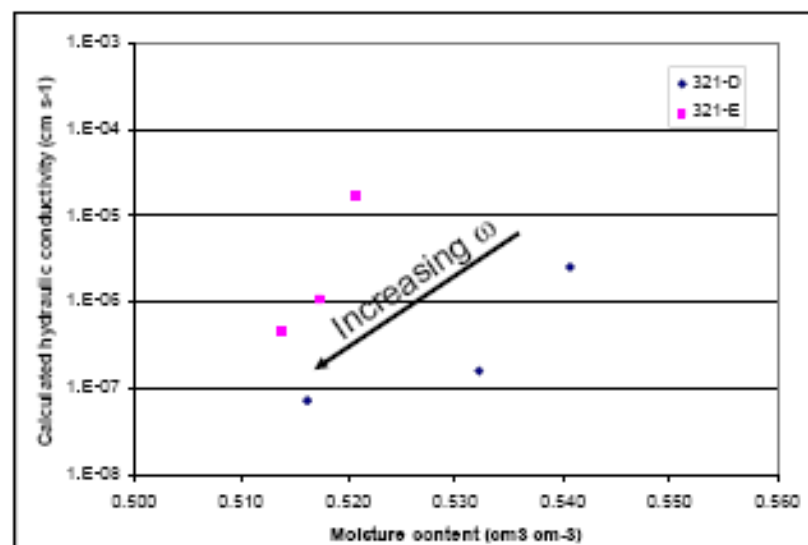

Figure 3. Attempt to determine unsaturated hydraulic conductivity values for the $\mathrm{Ca}(\mathrm{OH}) 2$ permeate solution

No unsaturated results were possible for the $\mathrm{NaOH}$ solution. Besides the problem described in the previous paragraphs, gas was generated during the $\mathrm{NaOH}$ unsaturated hydraulic conductivity testing in the centrifuge biasing the flux measurement. As gas is generated enters the cap and small diameter lines and results in an un-measurable solution flux into the sample. Addition work is needed to address the gas generation (see suggest work section).

Considering the small drainage for measured in the moisture retention analyses a conservative assumption would be to assume that the unsaturated moisture content is uniform and equal to the saturated hydraulic conductivity value over the range of matric potential measured. Otherwise the unsaturated hydraulic conductivity values as estimated by the van Genuchten method can be used.

van Genuchten Parameter Analysis

The moisture retention data (see moisture retention data result section) was used to develop van Genuchten transport parameter for the saltstone sub-cores. All moisture retention values were given a weight of 1 . The residual moisture was set to be 0.55 and we used the standard Mualem relationship between $\mathrm{n}$ and $\mathrm{m}$ (i.e. $\mathrm{m}=1-1 / \mathrm{n}$ ). A good regression analysis $\left(\mathrm{r}^{2}=0.96\right.$ ) was obtained only fitting the alpha, $n$, and the saturated moisture content. Figure 4 illustrates the data as a function of water content verses matric potential and the van Genuchten fitted relationship. 
Kenneth L. Dixon

October 9,2006

CCN 207262

Page 10

\begin{tabular}{|l|l|l|c|c|c|}
\hline & $\alpha(\mathrm{cm}-1)$ & $\mathrm{n}(-)$ & $\theta_{\mathrm{t}}\left(\mathrm{cm}^{3} \mathrm{~cm}^{-3}\right)$ & $\theta_{\mathrm{s}}\left(\mathrm{cm}^{3} \mathrm{~cm}^{-3}\right)$ & $\mathrm{K}_{\mathrm{str}}\left(\mathrm{cm} \mathrm{s}^{-1}\right)$ \\
\hline All data & 0.00156 & 1.3304 & .55 & .60 & $1.3 \mathrm{E}-08$ \\
\hline
\end{tabular}

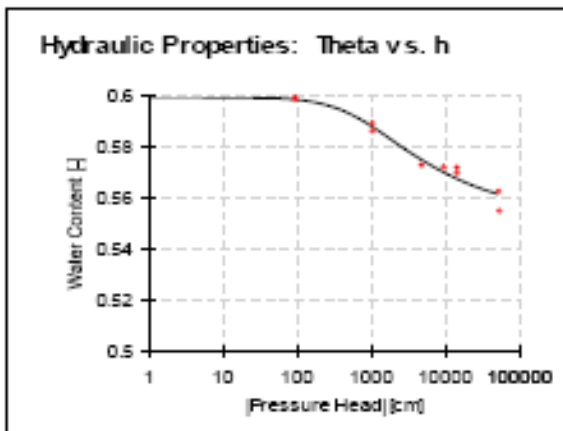

Figure 4. van Genuchten curve fit of the moisture retention data

\section{Suggest Future Work}

Hydraulic analysis of SRS saltstone material presents a number of challenges that are not typically encountered in traditional soil/rock testing. The testing of saltstone not only requires the proper equipment, but also the proper modification to the standard tests and some thought into various biases introduced while testing these samples. Below are a few notes of the testing and some suggested activities to address issues raised by this initial round of laboratory analyses.

1. There is a discrepancy between hydraulic analyses results described in this letter report and those previously reported. Previous work report higher bulk densities, lower porosities, and low saturated hydraulic conductivities. More recent laboratory results are more inline to those reported in this letter but still exhibit a much lower saturated hydraulic conductivity $(\sim 100$ times) that those calculated in this report. A careful review of the previous analyses (and these analyses) is needed to resolve differences between the studies.

2. Gas generation using the $\mathrm{NaOH}$ permeate solution is a problem for hydraulic analysis. During the saturated hydraulic testing using the standard and the centrifuge falling head method, gas was generated at the sample inlet. For the standard hydraulic testing, the gas accumulated in a small reservoir and was removed before taking measurements. For the centrifuge falling head test, the 
WSRC-STI-2007-00649, REVISION 0

Kenneth L. Dixon

October 9, 2006

CCN 207262

Page 11

inlet tubes are much smaller and removal of the gas is not possible. We first need to determine the source of the gas, and then we can design appropriate experiments to mitigate the gas generation. Two likely possibilities include a chemical reaction with the saltstone and/or a chemical reaction with the epoxy material. If the gas generation is associated with the epoxy, a simple fix should be achievable. If on the other hand, the gas generation is associated with the saltstone matrix, it could have significant implication to the hydraulic properties over the long term. A simple laboratory qualitative test could help distinguish the source of gas.

3. Despite the observed gas generation observed in this round of testing, saturated hydraulic conductivities reported in this letter report are greater than those reported by others. Generally, the generation of gas would result in lower hydraulic conductivities due to gas entrapment in porespaces. Other laboratories may have not noted this phenomena and it may explain their lower saturated hydraulic conductivities. On the other hand, it is possible that there is still preferential flow between the epoxy and the saltstone. Visual examination of the sub-cores after potting would suggest the binding of the epoxy and the saltstone was excellent. A dye tracer test should be performed and evaluated for signs of preferential flow in future work.

4. It is not completely evident if unsaturated hydraulic conductivity can be obtained using the UFA. I would suggest that we evaluate the steady state centrifuge method with a numerical evaluation (e.g. the modified HYDRUS 1D model) simulating various flux rates, rotational speeds, and sample lengths. Using data from this letter report, we could predict the expected matric potential and design an optimum experimental program. As part of this activity, I would recommend destructive sampling of the saltstone to measure the matric potential along its length.

5. A discrepancy was noted between the fitted saturated moisture content from the moisture retention data $(\sim 0.6)$ and the moisture content calculated at the end of the standard falling head test $(\sim 0.57)$. Typically a 0.03 variance between saturated moisture contents would not be a big issue. However for the saltstone material the residual moisture content is 0.55 and not a much lower value of a typical soil. This discrepancy may be due to gas generation and/or the coating of the walls of the saltstone with epoxy resulting in limited entrapped gas exit routes during solution saturation. This discrepancy illustrates the sensitivity of using measured moisture contents to predict matric potential. Additional characterization may be warranted and careful examination of how these hydraulic analyses are used in interpreting field results. 
WSRC-STI-2007-00649, REVISION 0

Kenneth L. Dixon

October 9,2006

CCN 207262

Page 12

6. Care was taken to prevent atmospheric $\mathrm{CO} 2$ from coming in contact with the alkaline solutions during testing. However in the field, the saltstone will not be isolated from $\mathrm{CO}_{2}$ sources and may actually be in an environment of higher $\mathrm{CO}_{2}$ concentrations. Long term issues of $\mathrm{CO}_{2}$ diffusion into the saltstone and the geochemical precipitation effects may need to be evaluated.

Sincerely,

Earl D. Mattson, Ph.D., Research Hydrologist

Geosciences

EDM:pgs 
WSRC-STI-2007-00649, REVISION 0

\section{APPENDIX D. GTX DATA SHEETS ON MCU SALTSTONE TESTING}




\section{GeoTesting \\ express}

\section{GTX TECHNICAL PROCEDURE T-03 UNIT WEIGHT OF SAMPLE}

Project No.: GTX G1071

Lab No: 20390

Project Name: Saltstone Grout Testing

Tested By: RMT

Date: $07 / 06 / 06$
Boring No.: N/A Depth: N/A

Sample ID: SLT-003

Reviewed By: JW

Date: $07 / 06 / 06$

\begin{tabular}{|c|c|c|c|c|c|c|}
\hline \multicolumn{2}{|c|}{$\begin{array}{l}\text { Total Sample } \\
\text { Height, inches }\end{array}$} & \multicolumn{2}{|c|}{$\begin{array}{c}\text { Inside Diameter } \\
\text { of Cut Tube, inches }\end{array}$} & \multicolumn{3}{|c|}{ Moisture Content } \\
\hline 1 & 4.371 & \multirow{3}{*}{$\begin{array}{r}\text { Top } \\
\text { Bottom }\end{array}$} & \multirow[b]{2}{*}{3.000} & Tare No. & & \multirow[b]{2}{*}{ grams } \\
\hline 2 & 4.371 & & & Tare Weight & 0.00 & \\
\hline 3 & 4.371 & & 3,000 & Wet Weight + Tare & 872.00 & grams \\
\hline \multirow[t]{2}{*}{ Average } & 4.37 & \multirow[t]{2}{*}{ Average } & 3.000 & Dry Weight + Tare & 605.68 & grams \\
\hline & & & & Moisture Content & 44.0 & $\%$ \\
\hline
\end{tabular}

\begin{tabular}{|lll|}
\hline Total Weight of Soil + Tube Section & 872.00 & grams \\
\cline { 2 - 2 } Weight of Clean, Dry Tube Section & 0.00 & grams \\
\cline { 2 - 3 } Wet Weight of Soil & 1.92 & lbs \\
\cline { 2 - 3 } Volume of Sample & 0.018 & $\mathrm{ft}^{3}$ \\
\hline
\end{tabular}

RESULT SUMMARY

\begin{tabular}{|c|c|c|}
\hline Moisture Content & 44.0 & $\%$ \\
\hline Wet Density & 107.5 & $p c f$ \\
\hline Dry Density & 74.7 & $p c f$ \\
\hline Specific Gravity & 2.45 & \\
\hline Porosity & 0.51 & \\
\hline
\end{tabular}

Remarks: WSRC Task 21, Contract No.: AB80188N 


\section{GeoTesting express}

\section{GTX TECHNICAL PROCEDURE T-03 UNIT WEIGHT OF SAMPLE}

Project No.: GTX G1071

Lab No: 20391

Project Name: Saltstone Grout Testing

Tested By: RMT

Date: $07 / 06 / 06$
Boring No.: N/A Depth: N/A

Sample ID: SLT-004

Reviewed By: JW Date: $07 / 06 / 06$

\begin{tabular}{|c|c|c|c|c|c|c|}
\hline \multicolumn{2}{|c|}{$\begin{array}{l}\text { Total Sample } \\
\text { Height, inches }\end{array}$} & \multicolumn{2}{|c|}{$\begin{array}{c}\text { Inside Diameter } \\
\text { of Cut Tube, inches }\end{array}$} & \multicolumn{3}{|c|}{ Moisture Content } \\
\hline 1 & 4.61 & \multirow{3}{*}{$\begin{array}{r}\text { Top } \\
\text { Bottom }\end{array}$} & \multirow[b]{2}{*}{3.000} & Tare No. & & \multirow[b]{2}{*}{ grams } \\
\hline 2 & 4.61 & & & Tare Weight & 0.00 & \\
\hline 3 & 4.61 & & 3.000 & Wet Weight + Tare & 926.50 & grams \\
\hline \multirow[t]{2}{*}{ Average } & 4.61 & \multirow[t]{2}{*}{ Average } & 3.000 & Dry Weight + Tare & 651.79 & grams \\
\hline & & & & Moisture Content & 42.1 & $\%$ \\
\hline
\end{tabular}

\begin{tabular}{|lll||}
\hline Total Weight of Soil + Tube Section & 926.50 & grams \\
\cline { 2 - 2 } Weight of Clean, Dry Tube Section & 0.00 & grams \\
\cline { 2 - 2 } Wet Weight of Soil & 2.04 & lbs \\
\cline { 2 - 3 } Volume of Sample & 0.019 & $\mathrm{ft}^{3}$ \\
\hline
\end{tabular}

RESULT SUMMARY

\begin{tabular}{|c|c|c|}
\hline Moisture Content & 42.1 & $\%$ \\
\hline Wet Density & 108.3 & $p c f$ \\
\hline Dry Density & 76.2 & $p c f$ \\
\hline Specific Gravity & 2.48 & \\
\hline Porosity & 0.51 & \\
\hline
\end{tabular}

Remarks: $\quad$ WSRA Task 21, Contract No, AB80188N 
GeoTesting express

a subsiditary of Geacomp Corporation

\begin{tabular}{|c|c|c|c|}
\hline Client: & WSRC & & \\
\hline Project Name: & Saltstone Grout Testing & & \\
\hline Project Location: & $\cdots$ & & \\
\hline GTX \#: & G1071 & & \\
\hline Start Date: & $6 / 30 / 2006$ & Tested By: & $\mathrm{mt}$ \\
\hline End Date: & $7 / 6 / 2006$ & Checked By: & jdt \\
\hline $\begin{array}{l}\text { Boring \#: } \\
\text { Sample \#: } \\
\text { Depth: } \\
\text { Visual Description: }\end{array}$ & $\begin{array}{l}\text { SLT-003 (20390) } \\
\text { Grout }\end{array}$ & Test * : & $k$ \\
\hline
\end{tabular}

\section{Hydraulic Conductivity of Saturated Porous Materials Using a Flexible Wall Permeameter by ASTM D 5084 Constant Volume}

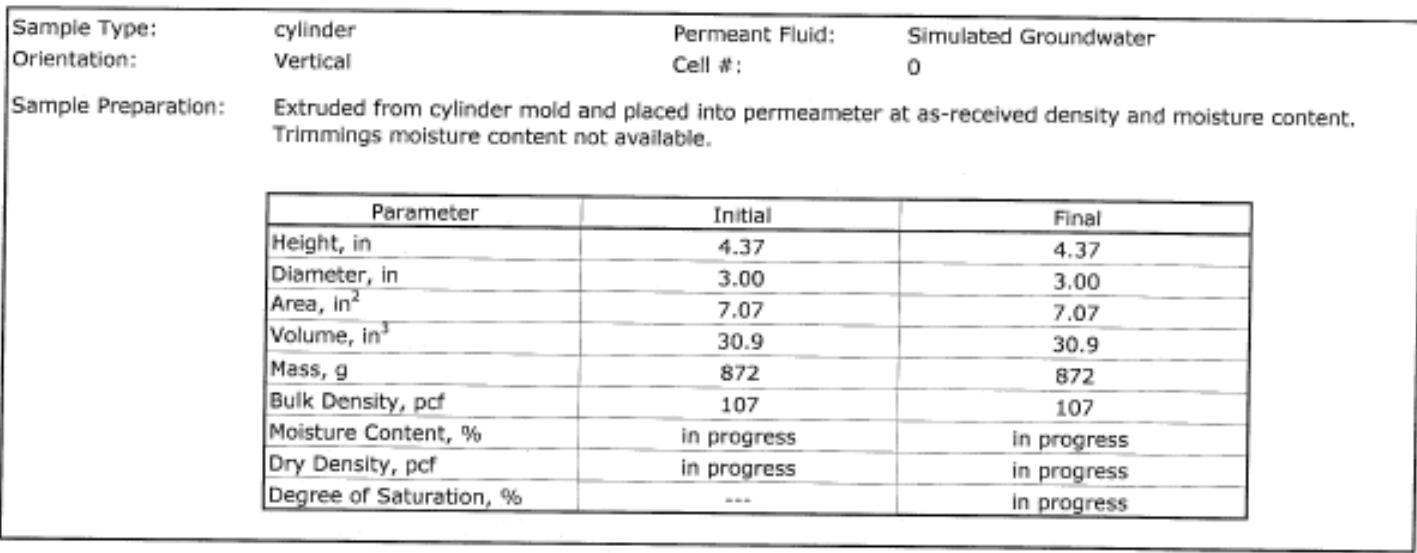

\begin{tabular}{|c|c|c|c|c|c|c|c|c|c|c|c|c|}
\hline $\begin{array}{l}\text { B COEF } \\
\text { Cell Pre } \\
\text { Sample } \\
\text { FLow }\end{array}$ & $\begin{array}{l}\text { FICIEN } \\
\text { sure, p } \\
\text { Pressur } \\
\text { ATA }\end{array}$ & $\begin{array}{l}\text { DETE } \\
\text { i: }\end{array}$ & RMINATIC & $\begin{array}{l}\text { ON } \\
95 \\
90.1\end{array}$ & & & $\begin{array}{l}\text { Pressure I } \\
\text { B Coefficie }\end{array}$ & $\begin{array}{l}\text { crement, } p \\
\text { ht: }\end{array}$ & & $\begin{array}{l}4.75 \\
0.95\end{array}$ & & \\
\hline Date & $\begin{array}{c}\text { Trial } \\
\# \\
\end{array}$ & $\begin{array}{l}\text { Pres } \\
\text { Cell }\end{array}$ & $\begin{array}{l}\text { ure, psi } \\
\text { Sample }\end{array}$ & $\begin{array}{l}\text { Man } \\
z_{1} \\
\end{array}$ & $\frac{\text { neter } \mathrm{Re}}{\mathrm{Z}_{2}}$ & $\begin{array}{l}\text { lings } \\
z_{1}-z_{2}\end{array}$ & $\begin{array}{c}\text { Elapsed } \\
\text { Time, } \\
\text { sec }\end{array}$ & Gradient & $\begin{array}{c}\text { Permeability } \\
\text { K, } \\
\mathrm{cm} / \mathrm{sec} \\
\end{array}$ & $\begin{array}{c}\text { Temp, } \\
{ }^{\circ} \mathrm{C}\end{array}$ & $\mathbf{R}_{t}$ & $\begin{array}{c}\text { Permeability } \\
\mathrm{K} \oplus 20^{\circ} \mathrm{C} \text {, } \\
\mathrm{cm} / \mathrm{sec}\end{array}$ \\
\hline $\begin{array}{l}7 / 6 \\
7 / 6 \\
7 / 6 \\
7 / 6\end{array}$ & $\begin{array}{l}1 \\
2 \\
3 \\
4\end{array}$ & $\begin{array}{l}90 \\
90 \\
90 \\
90\end{array}$ & $\begin{array}{l}85 \\
85 \\
85 \\
85\end{array}$ & $\begin{array}{l}26.0 \\
26.0 \\
26.0 \\
26.0\end{array}$ & $\begin{array}{l}25.5 \\
25.4 \\
25.5 \\
25.5\end{array}$ & $\begin{array}{l}0.5 \\
0.6 \\
0.5 \\
0.5\end{array}$ & $\begin{array}{c}793 \\
1096 \\
766 \\
750\end{array}$ & $\begin{array}{l}29.5 \\
29.5 \\
29.5 \\
29.5\end{array}$ & $\begin{array}{l}1.5 \mathrm{E}-08 \\
1.3 \mathrm{E}-08 \\
1.5 \mathrm{E}-08 \\
1.6 \mathrm{E}-08\end{array}$ & $\begin{array}{l}20 \\
20 \\
20 \\
20\end{array}$ & $\begin{array}{l}1.000 \\
1.000 \\
1.000 \\
1.000\end{array}$ & $\begin{array}{l}1.5 \mathrm{E}-08 \\
1.3 \mathrm{E}-08 \\
1.5 \mathrm{E}-08 \\
1.6 \mathrm{E}-08\end{array}$ \\
\hline
\end{tabular}

\section{PERMEABILITY AT $20^{\circ} \mathrm{C}: 1.5 \times 10^{-8} \mathrm{~cm} / \mathrm{sec}$ (@ 5 psi effective stress)}


GeoTesting

xpress

a subsidiary of Geocomp Corporation

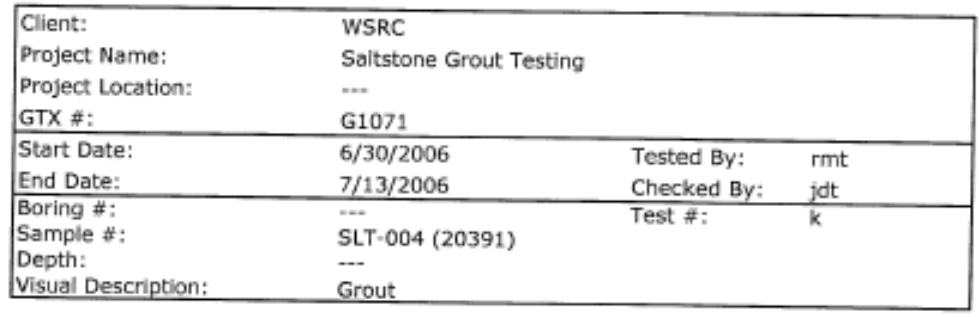

\section{Hydraulic Conductivity of Saturated Porous Materials Using a Flexible Wall Permeameter by ASTM D 5084 Constant Volume}

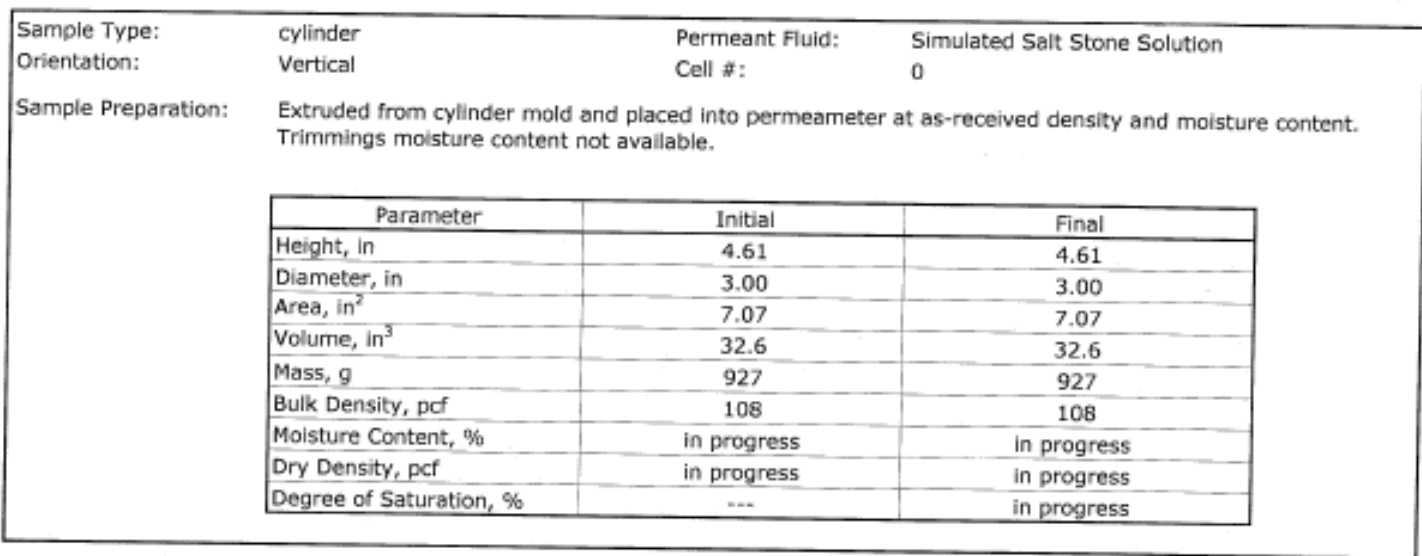

\begin{tabular}{|c|c|c|c|c|c|c|c|c|c|c|c|c|}
\hline \multirow{2}{*}{\multicolumn{4}{|c|}{$\begin{array}{l}\text { Cell Pressure, psi: } \\
\text { Sample Pressure, psi: } \\
\text { FLOW DATA }\end{array}$}} & \multirow{2}{*}{\multicolumn{3}{|c|}{$\begin{array}{l}95.5 \\
88.4\end{array}$}} & \multirow{2}{*}{\multicolumn{3}{|c|}{$\begin{array}{l}\text { Pressure Increment, psi: } \\
\text { B Coefficient: }\end{array}$}} & \multirow{2}{*}{\multicolumn{3}{|c|}{$\begin{array}{l}4.75 \\
0.95\end{array}$}} \\
\hline & & & & & & & & & & & & \\
\hline Date & $\begin{array}{c}\text { Trial } \\
\# \\
\end{array}$ & \multicolumn{2}{|c|}{ Pressure, psl } & \multicolumn{3}{|c|}{ Manometer Readings } & $\begin{array}{l}\text { Elapsed } \\
\text { Time, } \\
\text { sec }\end{array}$ & Gradient & $\begin{array}{c}\text { Permeability } \\
\mathrm{K} \text {, } \\
\mathrm{cm} / \mathrm{sec} \\
\end{array}$ & $\begin{array}{c}\text { Temp, } \\
{ }^{\circ} \mathrm{C}\end{array}$ & $R_{t}$ & $\begin{array}{c}\text { Permeability } \\
\mathrm{K} \oplus 20^{\circ} \mathrm{C} \text {, } \\
\mathrm{cm} / \mathrm{sec}\end{array}$ \\
\hline $\begin{array}{l}7 / 13 \\
7 / 13 \\
7 / 13 \\
7 / 13\end{array}$ & $\begin{array}{l}1 \\
2 \\
3 \\
4\end{array}$ & $\begin{array}{l}90 \\
90 \\
90 \\
90\end{array}$ & $\begin{array}{l}85 \\
85 \\
85 \\
85\end{array}$ & $\begin{array}{l}27.5 \\
27.5 \\
27.5 \\
27.5\end{array}$ & $\begin{array}{l}27.0 \\
27.3 \\
27.2 \\
27.4\end{array}$ & $\begin{array}{l}0.5 \\
0.2 \\
0.3 \\
0.1\end{array}$ & $\begin{array}{c}1931 \\
988 \\
1347 \\
440\end{array}$ & $\begin{array}{l}29.6 \\
29.6 \\
29.6 \\
29.6\end{array}$ & $\begin{array}{l}\text { 6.1E-09 } \\
4.7 \mathrm{E}-09 \\
5.2 \mathrm{E}-09 \\
5.3 \mathrm{E}-09\end{array}$ & $\begin{array}{l}20 \\
20 \\
20 \\
20\end{array}$ & $\begin{array}{l}1.000 \\
1.000 \\
1.000 \\
1.000\end{array}$ & $\begin{array}{l}6.1 \mathrm{E}-09 \\
4.7 \mathrm{E}-09 \\
5.2 \mathrm{E}-09 \\
5.3 \mathrm{E}-09\end{array}$ \\
\hline & & & & & & & & & & & & \\
\hline
\end{tabular}

PERMEABILITY AT $20^{\circ} \mathrm{C}: 5.3 \times 10^{-9} \mathrm{~cm} / \mathrm{sec}$ (@ 5 psi effective stress) 


\section{GeoTesting express}

\section{Water Retention Test} (ASTM D3152)

\begin{tabular}{|c|c|c|c|}
\hline Project No & GTX-G1071 & Project Name & Saltstone Grout Testing \\
\hline Tested By & SS & Test Date & $6 / 21 / 06$ \\
\hline Reviewed By & JW & Review Date & $6 / 29 / 06$ \\
\hline
\end{tabular}

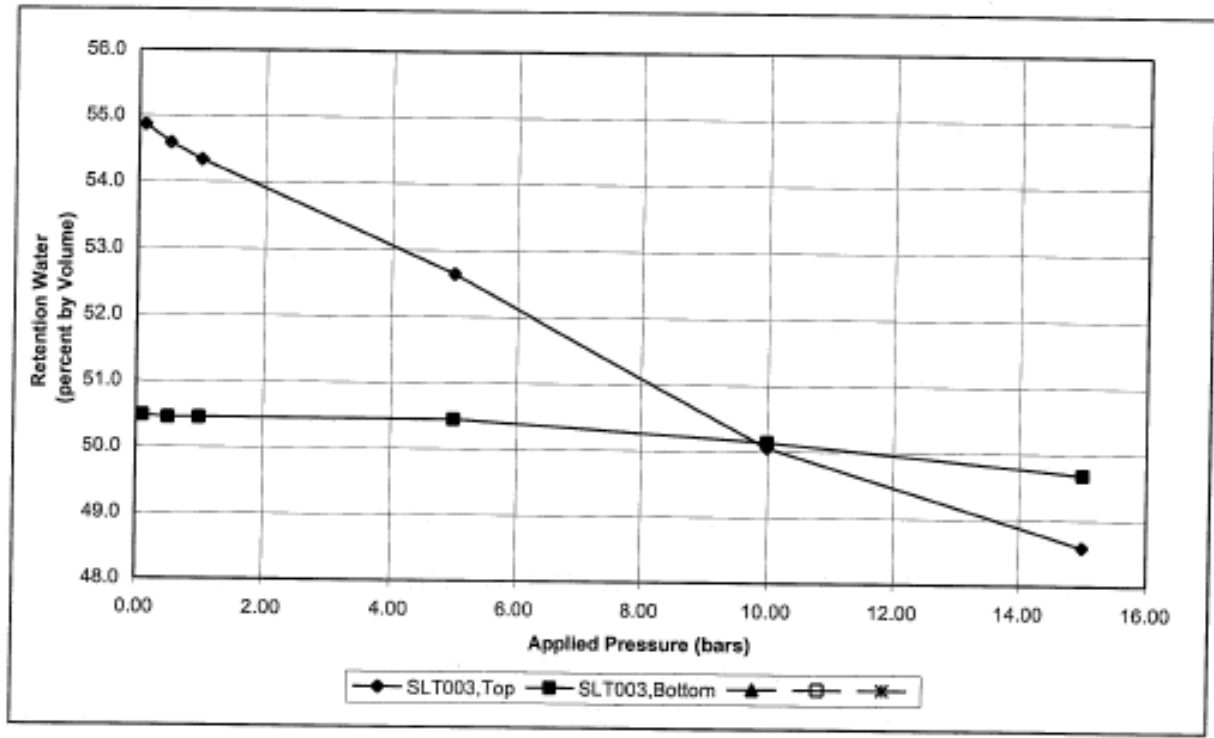

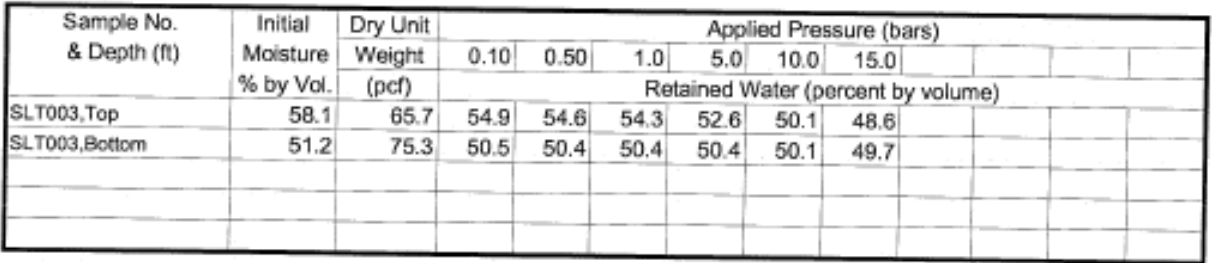

Remarks: The effective porosity (effective drainage porosily as defined by ASTM D653, as a percent, is found for an applied pressure by subtracting the retained percent water (by volume) from the saturation percent water.

Sample grades light to dark gray from top of sampie to bottom. Sampls saturated will Equilbratod Ground Water Simulant:

Sample teken from top of sample fractured during testing. Intial fracture after 0.1 BAR Pressure.

Final Sample Dimensions: (Bottom) diameter: $2.9638 \mathrm{~cm}$, Height: $0.2103 \mathrm{~cm}$ 


\section{GeoTesting \\ express}

\section{Water Retention Test}

(ASTM D3152)

\begin{tabular}{llll} 
Project No & GTX-G1071 & & $\begin{array}{l}\text { Project Name } \\
\text { Test Date } \\
\text { Tested By }\end{array}$ \\
Reviewed By & SS & $\begin{array}{l}\text { Saltstone Grout Testing } \\
\text { Review Date }\end{array}$ & $\underline{7 / 7 / 06}$ \\
\hline
\end{tabular}

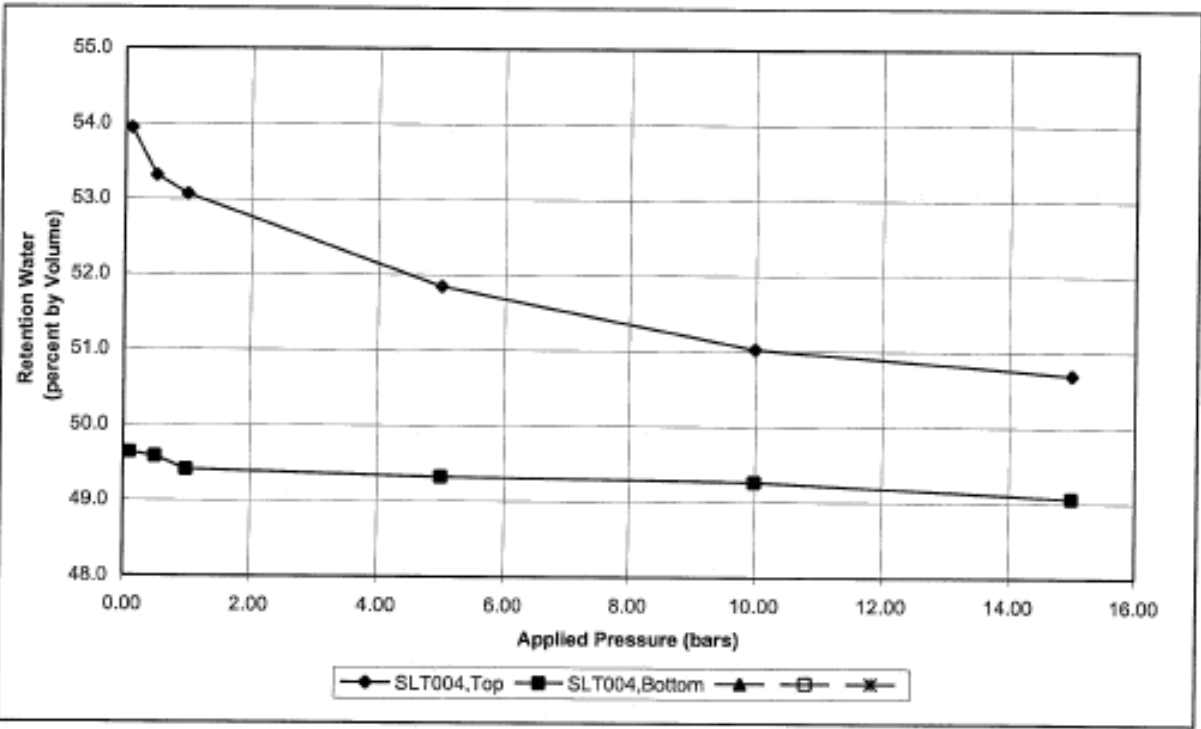

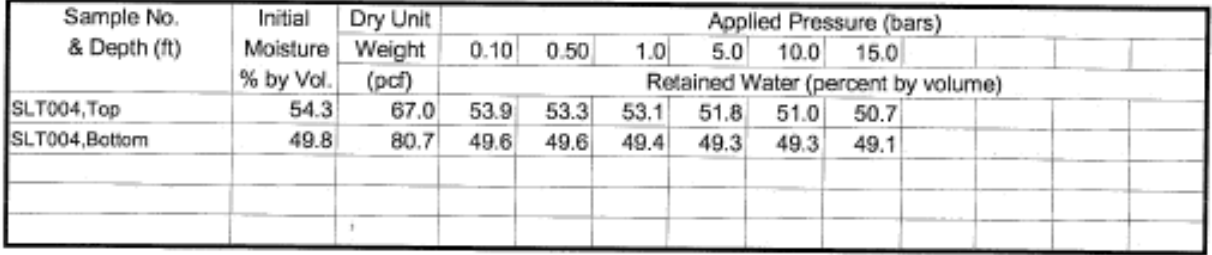

Remarks: The effective porceity (effective drainage porosity as definod by ASTM D653, as a percent, is found for an applied pressure by subtracting the retained percent water (by volume) from the saturation percent water.

Sample grades light to dark gray from top of sample to bottom. Sample saturatod with Simulated Saltstone Pore Fluid

Sample taken from top of sample fractured during testing. Intial fracture after 0.5 BAR Pressure.

2nd Fracture at 5.0 BAR; 3rd fracture at 10.0 BAR

Final Sarrple Dimensions: (Bottom) diameter: $2.9646 \mathrm{~cm}$, Height $0.3054 \mathrm{~cm}$ 
WSRC-STI-2007-00649, REVISION 0

\section{GeoTesting}

express

Water Retention Test (ASTM D3152)

$\begin{array}{ll}\text { Project No } & \text { GTX-G1071 } \\ \text { Tested By } & \text { SS } \\ \text { Reviewed By } & \text { JW }\end{array}$

Project Name
Test Date
Review Date

Saltstone Grout Testing

\begin{tabular}{llll} 
Tested By & SS & & $\begin{array}{l}\text { Test Date } \\
\text { Reviewed By }\end{array}$ \\
\cline { 2 - 3 } & JW & R/21/2006 \\
& &
\end{tabular}

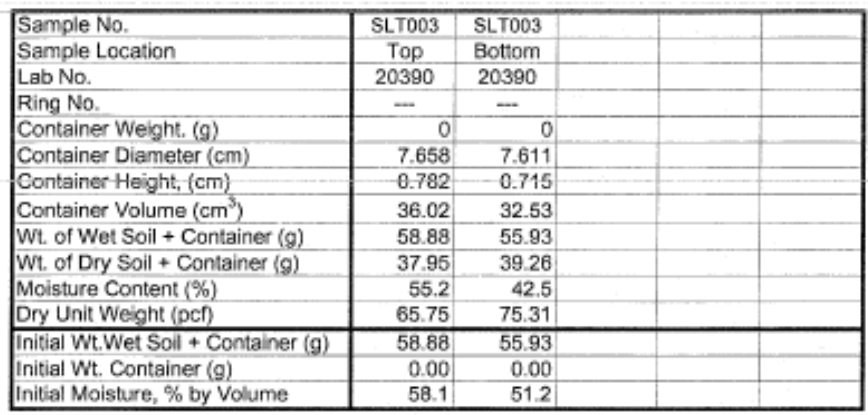

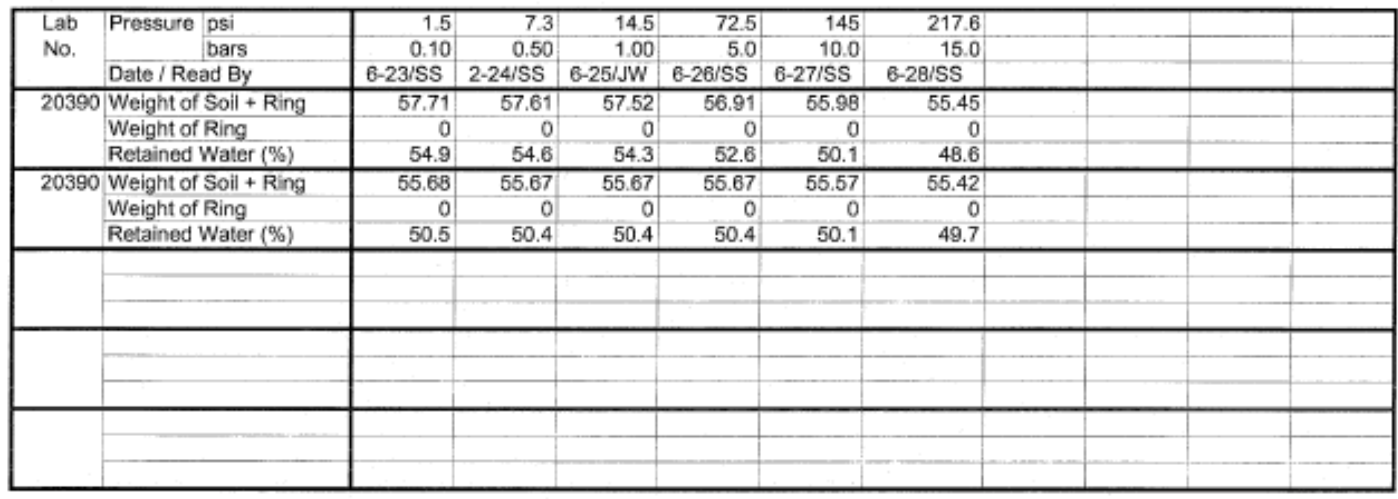

No. of Samples

No. of Tests per Sample

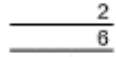


WSRC-STI-2007-00649, REVISION 0

\section{GeoTesting express}

Water Retention Test (ASTM D3152)

\begin{tabular}{|c|c|c|c|}
\hline Project No & GTX-G1071 & Project Name & Saltstone Grout Testing \\
\hline Tested By & SS & Test Date & $7 / 7 / 2006$ \\
\hline Reviewed By & $\overline{J W}$ & Review Date & $7 / 14 / 2006$ \\
\hline
\end{tabular}

\begin{tabular}{|c|c|c|c|c|}
\hline Sample No. & SLT004 & SLTO04 & & \\
\hline Sample Location & Top & Bottom & & \\
\hline Lab No. & 20391 & 20391 & & \\
\hline Ring No. & - & 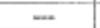 & & \\
\hline Container Weight. (g) & 0 & 0 & & \\
\hline Container Diameter (cm) & 7.633 & 7.615 & & \\
\hline Container Height, (cm) & 0.8014 & 0.7595 & & \\
\hline Container Volume $\left(\mathrm{cm}^{3}\right)$ & 36.67 & 34.59 & . & \\
\hline Wt of Wet Soil + Container $(g)$ & 59.25 & 61.98 & & \\
\hline Wt of Dry Soil + Container $(\mathrm{g})$ & 39.35 & 44.74 & & \\
\hline Moisture Content $(\%)$ & 50.6 & 38.5 & & \\
\hline Dry Unit Weight (pcf) & 66.96 & 80.71 & & \\
\hline Initial Wt.Wot Soil + Container (g) & 59.25 & 61.98 & & \\
\hline Initial WL. Container $(\mathrm{g})$ & 0.00 & 0.00 & & \\
\hline Initial Moisture, $\%$ by Volume & 54.3 & 49.8 & & \\
\hline
\end{tabular}

Remarks: Equilbrated Groundwater Simulant

Sample grades light to dark

from top to bottom.

from top to bottom.

Top sample fractured during

test

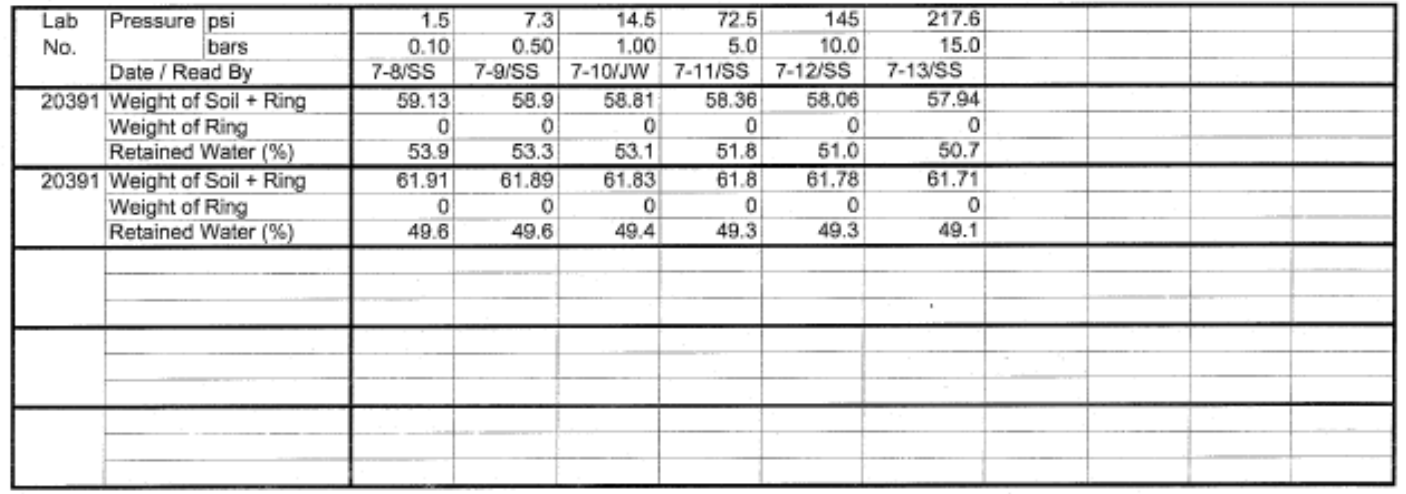

No. of Samples

No. of Tests per Sample

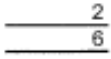


WSRC-STI-2007-00649, REVISION 0

\section{APPENDIX E. CALCULATIONS TO CORRECT FOR SALT PRECIPITATION}


The purpose of this appendix is to demonstrate the calculations that were used to correct the raw laboratory measurements of dry bulk density, porosity, and water retention for the saltstone grout samples. For each of these measurements, the sample is ultimately oven dried and it is necessary to correct for salt precipitation that occurs during this process.

Dry bulk density was calculated based on the following equations.

$$
\begin{gathered}
\psi_{\text {liquid }}=\frac{\rho_{\text {sat }}-\rho_{\text {oven }}}{\chi_{\text {wil }}} \\
\rho_{\text {dry }}=\rho_{\text {sat }}-\psi_{\text {liquid }}
\end{gathered}
$$

$\psi_{\text {liquid }}=$ unit mass of interstitial liquid in sample at saturation, $\mathrm{g} / \mathrm{cm}^{3}$

$\rho_{\text {sat }}=$ wet density of saturated sample, $\mathrm{g} / \mathrm{cm}^{3}$

$\rho_{\text {oven }}=$ oven dried density of sample, $\mathrm{g} / \mathrm{cm}^{3}$

$\chi_{\text {wil }}=$ mass fraction of water in interstitial liquid (0.68), fraction

$\rho_{\text {dry }}=$ dry bulk density, $\mathrm{g} / \mathrm{cm}^{3}$

For sample SLT003:

$$
\begin{gathered}
\rho_{\text {sat }}=1.72 \mathrm{~g} / \mathrm{cm}^{3} \\
\rho_{\text {oven }}=1.20 \mathrm{~g} / \mathrm{cm}^{3} \\
\chi_{\text {wil }}=0.68 \text { (grams of water per gram of simulant) } \\
\psi_{\text {liquid }}=\frac{1.724 \frac{\mathrm{g}}{\mathrm{cm}^{3}}-1.198 \frac{\mathrm{g}}{\mathrm{cm}^{3}}}{0.68} \\
\psi_{\text {liquid }}=0.773 \frac{\mathrm{g}}{\mathrm{cm}^{3}} \\
\rho_{\text {dry }}=1.72 \frac{\mathrm{g}}{\mathrm{cm}^{3}}-0.773 \frac{\mathrm{g}}{\mathrm{cm}^{3}} \\
\rho_{\text {dry }}=0.95 \frac{\mathrm{g}}{\mathrm{cm}^{3}}
\end{gathered}
$$


From the calculations above, the unit mass of interstitial liquid in the sample is $0.773 \mathrm{~g} / \mathrm{cm}^{3}$. Thus, a sample with a volume of $1 \mathrm{~cm}^{3}$ would have $0.773 \mathrm{~g}$ of interstitial liquid in it. Porosity was calculated on a unit volume basis as follows:

$$
\begin{aligned}
& V_{\text {liquid }}=\frac{M_{\text {liquid }}}{\rho_{\text {liquid }}} \\
& V_{\text {liquid }}=\frac{0.773 \mathrm{~g}}{1.261 \frac{\mathrm{g}}{\mathrm{cm}^{3}}} \\
& V_{\text {liquid }}=0.613 \mathrm{~cm}^{3} \\
& \phi=\frac{V_{\text {voids }}}{V_{\text {total }}}=\frac{V_{\text {liquid }}}{V_{\text {total }}} \\
& \phi=\frac{0.613 \mathrm{~cm}^{3}}{1 \mathrm{~cm}^{3}} \\
& \phi=0.613
\end{aligned}
$$

$\mathrm{M}_{\text {liquid }}=$ mass of interstitial liquid in sample at saturation, $\mathrm{g}$ $\mathrm{V}_{\text {voids }}=$ total volume of voids, $\mathrm{cm}^{3}$ $\mathrm{V}_{\text {liquid }}=$ volume of interstitial liquid in sample, $\mathrm{cm}^{3}$ $\mathrm{V}_{\text {total }}=$ total volume of sample, $\mathrm{cm}^{3}$ $\rho_{\text {liquid }}=$ density of interstitial liquid $\left(1.261 \mathrm{~g} / \mathrm{cm}^{3}\right), \mathrm{g} / \mathrm{cm}^{3}$ $\phi=$ porosity, fraction 
The following equations were used to determine the initial moisture content (i.e. porosity) of the water retention samples. It is important to note that only the mass of liquid removed by oven drying needs to be corrected for salt precipitation. The liquid removed by pressure extraction does not need to be corrected. Therefore, to determine the mass of liquid initially in the sample, the calculation is broken into two parts. The first part of the calculation determines the mass of liquid removed by pressure extraction and the second part determines the mass of liquid removed by the oven drying process at the end of the test (which is corrected for salt precipitation). The sum of these two values equals the total mass of liquid in the sample at saturation.

For SLT003:

1)Determine the total mass of interstitial liquid in the sample:

$$
\begin{aligned}
& M_{\text {liquid-pressure }}=M_{\text {sat }}-M_{\text {pressure-final }} \\
& M_{\text {liquid-pressure }}=55.93 \mathrm{~g}-55.42 \mathrm{~g} \\
& M_{\text {liquid-pressure }}=0.51 \mathrm{~g} \\
& M_{\text {liquid-oven }}=\frac{M_{\text {pressure-final }}-M_{\text {dry }}}{\chi_{\text {wil }}} \\
& M_{\text {liquid-oven }}=\frac{55.42 \mathrm{~g}-39.26 \mathrm{~g}}{0.68} \\
& M_{\text {liquid-oven }}=23.76 \mathrm{~g} \\
& M_{\text {liquid }}=M_{\text {liquid-pressure }}+M_{\text {liquid-oven }} \\
& M_{\text {liquid }}=0.51 \mathrm{~g}+23.76 \mathrm{~g} \\
& M_{\text {liquid }}=24.27 \mathrm{~g}
\end{aligned}
$$

$\mathrm{M}_{\text {liquid-pressure }}=$ mass of interstitial liquid removed by pressure extraction, $\mathrm{g}$ $\mathrm{M}_{\text {liquid-oven }}=$ mass of interstitial liquid removed by oven drying, $\mathrm{g}$

$\mathrm{M}_{\text {pressure-final }}=$ final mass of sample following pressure extraction, $\mathrm{g}$ $\mathrm{M}_{\text {sat }}=$ total mass of saturated sample, $\mathrm{g}$ $\mathrm{M}_{\text {liquid }}=$ mass of interstitial liquid in sample at saturation, $\mathrm{g}$ $\mathrm{M}_{\mathrm{dry}}=$ mass of oven dried sample, $\mathrm{g}$

$\chi_{\text {wil }}=$ mass fraction of water in interstitial liquid (0.68), fraction 
2)Determine the initial saturation (total porosity) of the sample:

$$
\begin{aligned}
& V_{\text {liquid }}=\frac{M_{\text {liquid }}}{\rho_{\text {liquid }}} \\
& V_{\text {liquid }}=\frac{24.27 \mathrm{~g}}{1.261 \frac{\mathrm{g}}{\mathrm{cm}^{3}}} \\
& V_{\text {liquid }}=19.25 \mathrm{~cm}^{3} \\
& \phi=\frac{V_{\text {voids }}}{V_{\text {total }}}=\frac{V_{\text {liquid }}}{V_{\text {total }}} \\
& \phi=\frac{19.25 \mathrm{~cm}^{3}}{32.53 \mathrm{~cm}^{3}} \\
& \phi=0.592
\end{aligned}
$$

$\mathrm{M}_{\text {liquid }}=$ mass of interstitial liquid in sample at saturation, $\mathrm{g}$ $\rho_{\text {liquid }}=$ density of interstitial liquid $\left(1.261 \mathrm{~g} / \mathrm{cm}^{3}\right), \mathrm{g} / \mathrm{cm}^{3}$

$\mathrm{V}_{\text {liquid }}=$ volume of interstitial liquid in sample, $\mathrm{cm}^{3}$

$\mathrm{V}_{\text {voids }}=$ total volume of voids, $\mathrm{cm}^{3}$

$\mathrm{V}_{\text {total }}=$ total volume of sample, $\mathrm{cm}^{3}$

$\phi=$ total porosity (saturation), fraction 
3)Determine the volumetric liquid content of the sample at a specific pressure increment. In this example, the volumetric liquid content at 0.1 bars is determined.

$$
\begin{aligned}
& M_{\text {solid }}=M_{\text {sat }}-M_{\text {liquid }} \\
& M_{\text {solid }}=55.93 \mathrm{~g}-24.27 \mathrm{~g} \\
& M_{\text {solid }}=31.66 \mathrm{~g} \\
& V_{\text {liquid }}=\frac{M_{\text {sample }}-M_{\text {solid }}}{\rho_{\text {liquid }}} \\
& V_{\text {liquid }}=\frac{55.68 \mathrm{~g}-31.66 \mathrm{~g}}{1.261 \frac{\mathrm{g}}{\mathrm{cm}^{3}}} \\
& V_{\text {liquid }}=19.05 \mathrm{~cm}^{3} \\
& \theta_{\text {liquid }}=\frac{V_{\text {liquid }}}{V_{\text {total }}} \\
& \theta_{\text {liquid }}=\frac{19.05 \mathrm{~cm}^{3}}{32.53 \mathrm{~cm}^{3}} \\
& \theta_{\text {liquid }}=0.585
\end{aligned}
$$

$\mathrm{M}_{\text {solid }}=$ corrected final dry weight of sample, $\mathrm{g}$

$\mathrm{M}_{\text {sat }}=$ total mass of saturated sample, $\mathrm{g}$

$\mathrm{M}_{\text {liquid }}=$ mass of interstitial liquid in sample at saturation, $\mathrm{g}$

$\mathrm{M}_{\text {sample }}=$ mass of sample at each pressure increment, $\mathrm{g}$

$\rho_{\text {liquid }}=$ density of interstitial liquid $\left(1.261 \mathrm{~g} / \mathrm{cm}^{3}\right), \mathrm{g} / \mathrm{cm}^{3}$

$\mathrm{V}_{\text {liquid }}=$ volume of liquid in sample at each pressure increment, $\mathrm{cm}^{3}$

$\mathrm{V}_{\text {total }}=$ total volume of sample, $\mathrm{cm}^{3}$

$\theta_{\text {liquid }}=$ volumetric liquid content of sample at each pressure increment, fraction 


\section{Distribution}

T. C. Robinson, Jr., 766-H

K. H. Rosenberger, 766-H

J. L. Newman, 766-H

J. J. Mayer, 773-42A

R. S. Aylward, 773-42A

B. T. Butcher, 773-43A

J. R. Harbour, 999-W

J. C. Griffin, 773-A

M. R. Millings, 773-42A

K. L. Dixon, 773-42A

M. A. Phifer, 773-42A

W. E. Jones, 773-42A

E. L. Wilhite, 773-43A

C. A. Langton, 773-43A

H. H. Burns, 999-W

STI (4), 703-43A

E\&CPT Files 773-43A, Rm. 213 